4 Frédéric Ebstein ${ }^{1,53}$, Sébastien Küry ${ }^{2,3,53}$, Victoria Most ${ }^{4}$, Cory Rosenfelt ${ }^{5}$, Marie-Pier Scott-

5 Boyer $^{6}$, Geeske M. van Woerden ${ }^{7,8,9}$, Thomas Besnard ${ }^{2,3}$, Jonas Johannes Papendorf ${ }^{1}$, Maja

6 Studencka-Turski ${ }^{1}$, Tianyun Wang ${ }^{10,47}$, Tzung-Chien Hsieh ${ }^{11}$, Richard Golnik ${ }^{12}$, Dustin

7 Baldridge $^{13}$, Cara Forster ${ }^{14}$, Charlotte de Konink ${ }^{7,8}$, Selina M.W. Teurlings ${ }^{7,8}$, Virginie

8 Vignard $^{2,3}$, Richard H. van Jaarsveld ${ }^{15}$, Lesley Ades $^{16,17}$, Benjamin Cogné2,3 Cyril Mignot $^{18,19}$,

9 Wallid Deb ${ }^{2,3}$, Marjolijn C.J. Jongmans ${ }^{15,20}$, F. Sessions Cole ${ }^{13}$, Marie-José H. van den

\section{De novo variants in the PSMC3 proteasome AAA-ATPase subunit gene cause neurodevelopmental disorders associated with type I interferonopathies}

Boogaard $^{15}$, Jennifer A. Wambach ${ }^{13}$, Daniel J. Wegner ${ }^{13}$, Sandra Yang ${ }^{14}$, Vickie Hannig ${ }^{21}$, Jennifer Ann Brault ${ }^{21}$, Neda Zadeh ${ }^{22}$, Bruce Bennetts ${ }^{23,24}$, Boris Keren ${ }^{25}$, Anne-Claire Gélineau $^{25}$, Zöe Powis ${ }^{26}$, Meghan Towne ${ }^{26}$, Kristine Bachman ${ }^{27}$, Andrea Seeley ${ }^{27}$, Anita E. Beck $^{28}$, Jennifer Morrison ${ }^{29}$, Rachel Westman ${ }^{30}$, Kelly Averill ${ }^{31}$, Theresa Brunet ${ }^{32,33}$, Judith Haasters $^{34}$, Melissa T. Carter ${ }^{35}$, Matthew Osmond ${ }^{36}$, Patricia G. Wheeler ${ }^{37}$, Francesca Forzano $^{38}$, Shehla Mohammed ${ }^{38}$, Yannis Trakadis ${ }^{39}$, Andrea Accogli ${ }^{39}$, Rachel Harrison ${ }^{40}$, Deciphering Developmental Disorders Study ${ }^{41}$, Care4Rare Canada Consortium ${ }^{42}$, Sophie Rondeau $^{43}$, Geneviève Baujat ${ }^{43}$, Giulia Barcia ${ }^{43}$, René Günther Feichtinger ${ }^{44}$, Johannes Adalbert Mayr ${ }^{44}$, Martin Preisel ${ }^{44}$, Frédéric Laumonnier ${ }^{45,46}$, Alexej Knaus ${ }^{11}$, Bertrand Isidor ${ }^{2,3}$, Peter Krawitz ${ }^{10}$, Uwe Völker ${ }^{47}$, Elke Hammer ${ }^{47}$, Arnaud Droit ${ }^{6}$, Evan E. Eichler ${ }^{10,48}$, Ype Elgersma $^{8,9}$, Peter W. Hildebrand ${ }^{4,49,50}$, François Bolduc ${ }^{5,51,52,53}$, Elke Krüger ${ }^{1,54, \#}$ and Stéphane Bézieau ${ }^{2,3,54, \#}$

${ }^{1}$ Institut für Medizinische Biochemie und Molekularbiologie (IMBM), Universitätsmedizin Greifswald, Ferdinand-Sauerbruch-Straße, 17475 Greifswald, Germany;

${ }^{2} \mathrm{CHU}$ Nantes, Service de Génétique Médicale, 44093 Nantes, France;

${ }^{3}$ I'Institut du Thorax, INSERM, CNRS, Université de Nantes, Nantes, France;

${ }^{4}$ Institut für Medizinische Physik und Biophysik, Universität Leipzig, Medizinische Fakultät, Härtelstr. 16-18, 04107 Leipzig, Germany; 
${ }^{5}$ Department of Pediatrics, University of Alberta, Edmonton, AB, Canada;

${ }^{6}$ Research Center of Quebec CHU-Université Laval, Québec, QC PQ G1E6W2, Canada;

${ }^{7}$ Department of Neuroscience, Erasmus University Medical Center, 3015 CN, Rotterdam, The Netherlands;

${ }^{8}$ ENCORE Expertise Center for Neurodevelopmental Disorders, Erasmus University Medical Center, 3015 CN, Rotterdam, The Netherlands;

${ }^{9}$ Department of Clinical Genetics, Erasmus University Medical Center, 3015 CN, Rotterdam, The Netherlands

${ }^{10}$ Department of Genome Sciences, University of Washington School of Medicine, Seattle, WA 98195, USA;

${ }^{11}$ Institute for Genomic Statistics and Bioinformatics, University Hospital Bonn, Rheinische Friedrich-Wilhelms-Universität Bonn, Bonn, Germany;

${ }^{12}$ Klinik für Pädiatrie I, Universitätsklinikum Halle (Saale), 06120 Halle (Saale);

${ }^{13}$ The Edward Mallinckrodt Department of Pediatrics, Washington University School of Medicine, St. Louis, MO, USA;

${ }^{14}$ GeneDx, 207 Perry Parkway, Gaithersburg, MD 20877, USA;

${ }^{15}$ Department of Genetics, University Medical Center Utrecht, Utrecht, The Netherlands;

${ }^{16}$ Department of Clinical Genetics, The Children's Hospital at Westmead, Locked Bag 4001, Westmead, NSW, 2145, Australia;

${ }^{17}$ Disciplines of Genomic Medicine \& Child and Adolescent Health, Faculty of Medicine and Health, University of Sydney, Sydney, NSW, 2145, Australia;

${ }^{18}$ APHP, Hôpital Pitié-Salpêtrière, Département de Génétique, Centre de Reference Déficience Intellectuelle de Causes Rares, GRC UPMC «Déficience Intellectuelle et Autisme», Paris, France;

${ }^{19}$ Sorbonne Universités, Institut du Cerveau et de la Moelle épinière, ICM, Inserm U1127, CNRS UMR 7225, F-75013, Paris, France;

${ }^{20}$ Princess Máxima Center for Pediatric Oncology, Utrecht, The Netherlands;

${ }^{21}$ Department of Medicine, Vanderbilt University Medical Center, Nashville, Tennessee, USA; 
$57{ }^{22}$ Genetics Center, Orange, CA 92868, USA; Division of Medical Genetics, Children's 58 Hospital of Orange County, Orange, CA 92868, USA;

$59 \quad{ }^{23}$ Disciplines of Genomic Medicine \& Child and Adolescent Health, Faculty of Medicine and 60 Health, University of Sydney, Sydney, NSW, 2145, Australia;

$61 \quad{ }^{24}$ Sydney Genome Diagnostics, Western Sydney Genetics Program, The Children's Hospital 62 at Westmead, Sydney, NSW, Australia;

$63{ }^{25}$ Département de Génétique, Centre de Référence des Déficiences Intellectuelles de 64 Causes Rares, Groupe Hospitalier Pitié-Salpêtrière, Assistance Publique-Hôpitaux de Paris, 6575013 Paris;

$66{ }^{26}$ Department of Clinical Research, Ambry Genetics, Aliso Viejo, CA 92656, USA;

$67{ }^{27}$ Genomic Medicine Institute, Geisinger, Danville, PA, USA;

$68{ }^{28}$ Department of Pediatrics, Division of Genetic Medicine, University of Washington \& Seattle 69 Children's Hospital, Seattle, WA, USA;

$70{ }^{29}$ Division of Genetics, Arnold Palmer Hospital for Children, Orlando Health, Orlando, FL 71 32806, USA;

$72{ }^{30}$ Division of Genetics, St. Luke's Clinic, Boise, ID, USA;

$73 \quad{ }^{31}$ UT Health Science Center at San Antonio, Department of Pediatrics, Division of Pediatric 74 Neurology, San Antonio, TX 78229, USA;

$75 \quad{ }^{32}$ Institute of Human Genetics, Technical University of Munich, School of Medicine, 81675 76 Munich, Germany;

$77{ }^{33}$ Institute of Neurogenomics (ING), Helmholtz Zentrum München, German Research Center 78 for Environmental Health, 85764 Neuherberg, Germany;

$79{ }^{34}$ Klinikum der Universität München, Integriertes Sozial- pädiatrisches Zentrum, 80337 80 Munich, Germany;

$81{ }^{35}$ Department of Genetics, Children's Hospital of Eastern Ontario, Ottawa, Ontario, Canada;

$82{ }^{36}$ Children's Hospital of Eastern Ontario Research Institute, University of Ottawa, Ottawa, 83 Canada; 
${ }^{37}$ Division of Genetics, Arnold Palmer Hospital for Children, Orlando Health, Orlando, FL 32806, USA;

${ }^{38}$ Clinical Genetics Department, Guy's \& St Thomas' NHS Foundation Trust, London, UK;

${ }^{39}$ Division of Medical Genetics, McGill University Health Centre, Montreal, QC, Canada;

${ }^{40}$ Department of Clinical Genetics, Nottingham University Hospitals NHS Trust, City Hospital Campus, The Gables, Gate 3, Hucknall Road, Nottingham, NG5 1PB, UK;

${ }^{41}$ Wellcome Trust Sanger Institute, Wellcome Trust Genome Campus, Hinxton, Cambridge, UK.

${ }^{42}$ Children's Hospital of Eastern Ontario Research Institute, University of Ottawa, Canada;

${ }^{43}$ Service de Médecine Génomique des Maladies Rares, Hôpital Universitaire NeckerEnfants Malades, 75743 Paris, France;

${ }^{44}$ University Children's Hospital, Salzburger Landeskliniken (SALK) and Paracelsus Medical University (PMU), Salzburg, Austria;

${ }^{45}$ UMR 1253, iBrain, Université de Tours, Inserm, Tours, France;

${ }^{46}$ Service de Génétique, Centre Hospitalier Régional Universitaire, Tours, France;

${ }^{47}$ Universitätsmedizin Greifswald, Interfakultäres Institut für Genetik und Funktionelle Genomforschung, Abteilung für Funktionelle Genomforschung, 17487 Greifswald, Germany;

${ }^{48}$ Howard Hughes Medical Institute, Seattle, WA, 98195, USA;

${ }^{49}$ Institute of Medical Physics and Biophysics, Charité University Medicine Berlin, Berlin, Germany;

${ }^{50}$ Berlin Institute of Health, Berlin, Germany;

${ }^{51}$ Neuroscience and Mental Health Institute, University of Alberta, Edmonton, AB, Canada;

${ }^{52}$ Department of Medical Genetics, University of Alberta, Edmonton, AB, Canada;

${ }^{53}$ The authors equally contributed to this work.

${ }^{54}$ The authors equally contributed to this work.

"corresponding authors: 
medRxiv preprint doi: https://doi.org/10.1101/2021.12.07.21266342; this version posted December 7, 2021. The copyright holder for this preprint

(which was not certified by peer review) is the author/funder, who has granted medRxiv a license to display the preprint in perpetuity.

All rights reserved. No reuse allowed without permission.

111 Professor Elke Krüger, Email: elke.krueger@uni-greifswald.de; Professor Stéphane Bézieau,

112 Email: stephane.bezieau@chu-nantes.fr

113

114 Word count for the manuscript: 6292.

115 
medRxiv preprint doi: https://doi.org/10.1101/2021.12.07.21266342; this version posted December 7, 2021. The copyright holder for this preprint

(which was not certified by peer review) is the author/funder, who has granted medRxiv a license to display the preprint in perpetuity.

All rights reserved. No reuse allowed without permission.

Abstract

117 A critical step in preserving protein homeostasis by the ubiquitin-proteasome system (UPS)

118 is the recognition, binding, unfolding, and translocation of protein substrates by AAA-ATPase

119 proteasome subunits for degradation by $26 \mathrm{~S}$ proteasomes. Here, we identified fourteen

120 different de novo missense variants in the PSMC3 gene encoding the AAA-ATPase

121 proteasome subunit Rpt5 in twenty-two unrelated heterozygous subjects with an autosomal

122 dominant form of neurodevelopmental delay and intellectual disability. Indeed, depletion of

123 PSMC3 impaired reversal learning capabilities in a Drosophila model. The PSMC3 variants

124 cause proteasome dysfunction in patient-derived cells by disruption of substrate

125 translocation, proteotoxic stress and proteostatic imbalances, as well as alterations in

126 proteins controlling developmental and innate immune programs. Molecular analysis

127 confirmed the induction of cellular stress responses and dysregulated mitophagy along with

128 an elevated type I interferon (IFN) signature. Our data define PSMC3 variants as the genetic

129 cause of proteotoxic stress alerting the innate immune system to mount a type I IFN

130 response and link neurodevelopmental syndromes to interferonopathies.

131

132 Word count for the Abstract: 160. 
medRxiv preprint doi: https://doi.org/10.1101/2021.12.07.21266342; this version posted December 7, 2021. The copyright holder for this preprint (which was not certified by peer review) is the author/funder, who has granted medRxiv a license to display the preprint in perpetuity.

All rights reserved. No reuse allowed without permission.

Proteasomes are large multi-protein complexes whose structure is adapted to the function of

protein degradation $[1,2]$. Together with the autophagosomal-lysosomal system, it maintains

protein homeostasis by counterbalancing the synthesis of new proteins by the translational machinery [3-6]. The proteasome is part of the ubiquitin-proteasome system (UPS) which counts numerous enzymes acting upstream of the proteasome [7, 8]. Aged or unstructured proteins are preliminary ubiquitin-tagged by the ubiquitination machinery through a cascade of enzymatic reactions [9, 10]. Ubiquitin modification is a signal recognized by the $26 \mathrm{~S}$ proteasome which then takes in charge the hydrolysis of the substrate.

The 26S proteasome consists of two parts, the 20S core proteolytic particle and the 19S regulatory particle which caps the $20 \mathrm{~S}$ particle at one and/or both ends $[11,12]$. Briefly, polyubiquitinated proteins are recognized by the 19S regulatory particle where they are unfolded and deubiquitinated before their ATP-dependent translocation into the $20 \mathrm{~S}$ core particle $[13,14]$. There, proteins are hydrolyzed into small peptides by the $\beta 5, \beta 1$ and $\beta 2$ catalytic subunits that exhibit chymotrypsin-, trypsin and caspase-like activities, respectively $[15,16]$. Depending on the nature of the catalytic subunits, two major forms of proteasomes exist, namely the standard ones containing the $\beta 1, \beta 2$ and $\beta 5$ catalytic standard subunits and the immunoproteasomes harboring the $\beta 1 \mathrm{i}, \beta 2 \mathrm{i}$ and $\beta 5 \mathrm{i}$ inducible subunits [17]. While standard proteasomes are expressed in virtually all types of tissues, the expression of the inducible subunits is restricted to immune cells and non-immune cells exposed to type I and/or II interferons (IFN) [18, 19].

In more details, the 195 regulatory particle comprises two parts: a base and a lid. In the base, four regulatory particle non-ATPase subunits (i.e. Rpn1, Rpn2, Rpn10 and Rpn13) ensure recognition and capture of ubiquitin-modified substrates [20], whereas six AAA 160 (ATPase Associated with various cellular Activities)-ATPase subunits, namely PSMC1-6 161 (also referred to as Rpt1-6) use the energy provided by ATP hydrolysis to unfold and 
162 translocate the substrate into the $20 \mathrm{~S}$ proteolytic core particle by gate opening [21]. The lid

163 contains eight non-ATPase scaffolding subunits (Rpn3, Rpn5-9, Rpn12, and Rpn15) [22, 23],

164 and the deubiquitinating enzyme (DUB) Rpn11 [24].

166 Pathogenic variants in proteasome subunit genes cause rare proteasomopathies with a 167 broad spectrum of symptoms [25, 26]. So far, with the exception of the PSMB1 (i.e. $\beta 6$ ) subunit [27], all pathogenic variants related to the $20 \mathrm{~S}$ core particle have been shown to provoke immune dysregulation. Indeed, several genes encoding $\beta$-subunits (PSMB4, PSMB8, PSMB9, PSMB10), a-subunits (PSMA3) or assembly chaperone genes (POMP, PSMG2) of the 20 S proteasome complex have been involved in autosomal recessive proteasome-associated autoinflammatory syndromes (PRAAS) [28-35]. By contrast, the only Mendelian disorder involving a gene of the 19S regulatory particle, the Stankiewicz-Isidor syndrome (MIM: 617516) caused by truncating variants of PSMD12 (also referred to as Rpn5) is a neurodevelopmental polymalformative syndrome [36], recently associated with a mild interferonopathy (Isidor et al., in press).

In this work, we identify a series of fourteen dominant de novo variants in the PSMC3 gene coding for the AAA-ATPase PSMC3/Rpt5. Rare missense variants were detected in twentytwo individuals presenting with neurodevelopmental delay (NDD) and/or intellectual disability (ID) together with various congenital malformations. Together, our data highlight interferonopathy as a potential contributor to the pathogenesis of NDD/ID in subjects carrying loss-of-function variants in subunits of the 19S proteasome regulatory particle. 
medRxiv preprint doi: https://doi.org/10.1101/2021.12.07.21266342; this version posted December 7, 2021. The copyright holder for this preprint (which was not certified by peer review) is the author/funder, who has granted medRxiv a license to display the preprint in perpetuity.

All rights reserved. No reuse allowed without permission.

Materials \& Methods

\section{Genetic studies and ethics statement}

187 This study was approved by the CHU de Nantes ethics committee (Research Programme "Génétique Médicale DC-2011-1399). Written informed consent was obtained from all study participants, including probands and healthy parents. All affected individuals were initially referred for unexplained developmental delay (DD) and/or intellectual disability (ID) together with various congenital malformations. They underwent extensive clinical examination by at least one expert clinical geneticist. Routine genetic testing was performed whenever clinically relevant, including copy number variation (CNV) analysis by high-resolution array-based comparative genomic hybridization (aCGH). As these tests provided no diagnosis, trio-based whole exome sequencing (WES) was performed on a diagnostic or research setting whenever parental samples were available.

\section{Patient samples}

Peripheral blood mononuclear cells (PBMC) used in this paper were isolated from blood draws from patients and related healthy controls (father and/or mother of the proband). Briefly, PBMC were isolated by PBMC spin medium gradient centrifugations (pluriSelect), washed three times with PBS, frozen in FBS with 10\% DMSO and stored in liquid nitrogen for further use. In some experiments, collected PBMC were expanded in U-bottom 96-well plates together with feeder cells using RPMI 1640 supplemented with $10 \%$ human AB serum (both purchased from PAN-Biotech $\mathrm{GmbH}$ ) in the presence of $150 \mathrm{U} / \mathrm{ml}$ IL-2 (Miltenyi Biotec) and $1 \mu \mathrm{g} / \mu \mathrm{l} \mathrm{L-PHA} \mathrm{(Sigma)} \mathrm{following} \mathrm{the} \mathrm{procedure} \mathrm{of} \mathrm{Fonteneau} \mathrm{et} \mathrm{al.} \mathrm{[37].} \mathrm{After} \mathrm{3-4} \mathrm{weeks}$ of culture, resting $T$ cells were washed and frozen as dry pellets for further use.

208

\section{SDS-PAGE and western-blot analysis}

210 Cell pellets from resting $T$ cell isolated from patients and related controls were lysed in equal 211 amounts of standard RIPA buffer (50 mM Tris pH 7.5, $150 \mathrm{mM} \mathrm{NaCl}, 2 \mathrm{mM}$ EDTA, $1 \mathrm{mM} \mathrm{N}$ 212 ethylmaleimide, $10 \mu \mathrm{M}$ MG-132, 1\% NP40, 0.1\% SDS) and separated by 10 or $12.5 \%$ SDS- 
medRxiv preprint doi: https://doi.org/10.1101/2021.12.07.21266342; this version posted December 7, 2021. The copyright holder for this preprint (which was not certified by peer review) is the author/funder, who has granted medRxiv a license to display the preprint in perpetuity.

All rights reserved. No reuse allowed without permission.

213 PAGE before transfer to PVDF membranes (200V for 1h). After blocking (20-min exposure to

$2141 \mathrm{X}$ Roti®-Block at room temperature), membranes were probed with relevant primary 215 antibodies overnight at $4^{\circ} \mathrm{C}$ under shaking. The anti-a6 (clone MCP20), anti- $\alpha 7$ (clone 216 MCP72), anti- $\beta 1$ (clone MCP421), anti-PSMC2 (BML-PW8315) and anti-PSMC3 (BML217 PW8310) primary antibodies were purchased from Enzo Life Sciences. Primary antibodies 218 specific for TCF11/Nrf1 (clone D5B10), ubiquitin (clone D9D5), GAPDH (clone 14C10), 219 PINK1 (clone D8G3), BNIP3L/NIX (clone D8G3), LC3b (\#2775), elF2a (\#9722), phosphoelF2a (ser51, \#119A11) were obtained from Cell Signaling Technology. The anti-PSMD12 antibody (clone H3) was a purchase from Santa Cruz Biotechnology Inc. The anti-PA28-a (K232/1) is laboratory stock and was used in previous studies [33]. Antibodies directed against $\beta 5$ (ab3330), $\alpha$-Tubulin (clone DM1A) and phospho-PKR (Thr446, clone E120) were purchased from Abcam. Following incubation with primary antibodies, membranes were washed three times with PBS/0.2\% Tween and subsequently incubated with anti-mouse or rabbit HRP conjugated secondary antibodies $(1 / 5.000)$ for $1 \mathrm{~h}$ at room temperature. Proteins were then visualized using an enhanced chemiluminescence detection kit (ECL) (Biorad).

\section{Native PAGE and proteasome in-gel peptidase activity assay}

Cell pellets from resting $\mathrm{T}$ cell isolated from patients and related controls were lysed in icecold homogenization TSDG buffer (10 mM Tris pH 7.0, $10 \mathrm{mM} \mathrm{NaCl}, 25 \mathrm{mM} \mathrm{KCl}, 1.1 \mathrm{mM}$ $\mathrm{MgCl}_{2}, 0.1 \mathrm{mM}$ EDTA, $2 \mathrm{mM}$ DTT, $2 \mathrm{mM} \mathrm{ATP}, 1 \mathrm{mM} \mathrm{NaN}$, $20 \%$ Glycerol) and proteins were extracted using freeze/thawing in liquid nitrogen. Protein quantification of the soluble lysates was determined using a standard bicinchoninic acid assay (BCA) from Thermo Fisher Scientific. Twenty micrograms of whole-cell lysates were run on 3-12\% gradient Bis-Tris gels (Thermo Fisher Scientific) at $45 \mathrm{~V}$ overnight at $4^{\circ} \mathrm{C}$ using an electrophoresis buffer consisting of $50 \mathrm{mM}$ BisTris and $50 \mathrm{mM}$ Tricine (pH 6,8). Following separation, peptidase activity of the proteasome was measured by incubating the gels with $0.1 \mathrm{mM}$ of the suc-LLVY-AMC fluorogenic peptide (Bachem) at $37^{\circ} \mathrm{C}$ for $20 \mathrm{~min}$ in an overlay buffer ( $20 \mathrm{mM}$ Tris, $5 \mathrm{mM}$ 
medRxiv preprint doi: https://doi.org/10.1101/2021.12.07.21266342; this version posted December 7, 2021. The copyright holder for this preprint (which was not certified by peer review) is the author/funder, who has granted medRxiv a license to display the preprint in perpetuity.

All rights reserved. No reuse allowed without permission.

$240 \mathrm{MgCl}_{2}, \mathrm{pH}$ 7,0). Proteasome bands were subsequently visualized by exposing the gel to UV

241 light at $360 \mathrm{~nm}$ and detected at $460 \mathrm{~nm}$ using an Imager.

242

243 RNA isolation, reverse-transcription and PCR analysis

244 Total RNA was isolated from resting T cells using the kit from Analytic Jena AG following the

245 manufacturer's instructions. For subsequent real-time PCR, 100-500 $\mathrm{ng}$ of the isolated total

246 RNA was reverse transcribed using the M-MLV reverse transcriptase (Promega).

247 Quantitative PCR was performed using the Premix Ex Taq ${ }^{\mathrm{TM}}$ (probe qPCR purchased from

$248 \mathrm{TaKaRa}$ ) and in duplicates to determine the mRNA levels of each IFN-stimulated gene (ISG)

249 using FAM-tagged TaqMan ${ }^{\mathrm{TM}}$ Gene Expression Assays obtained from Thermo Fisher

250 Scientific according to the manufacturer's instructions. TaqMan ${ }^{\mathrm{TM}}$ probes used in this study

251 for ISG quantification included IFI27, IFI44L, IFIT1, ISG15, RSAD2, IFI44, MX1, OASL1,

252 CXCL9 and CXCL10. The cycle threshold (Ct) values for target genes were converted to

253 values of relative expression using the relative quantification (RQ) method $\left(2^{-\Delta \Delta C t}\right)$. Target

254 gene expression was calculated relative to $\mathrm{Ct}$ values for the GAPDH control housekeeping

255 gene.

256

257 Behavioural studies

258 Drosophila melanogaster (fruit flies) were raised on standard cornmeal-yeast media 259 developed at Cold Spring Harbor Laboratory in an incubator at $23^{\circ} \mathrm{C}$ with $40 \%$ humidity as 260 before [38]. Flies used for behaviour experiments included w1118 2202U (2U), Elav-Gal4. 261 and UAS-RNAi lines targeting PMSC3 orthologues. We identified the Drosophila ortholog of 262 PSMC3, Rpt5, using the DRSC Integrative Ortholog Prediction Tool 263 (https://www.flyrnai.org/diopt). UAS-Rpt5 RNAi (TRiP) lines were obtained from Bloomington 264 Drosophila Stock Center. We used the standard spatial restricted expression system Gal4265 UAS to pan-neuronally express (using pan-neuronal driver Elav) the RNAi against the 266 Drosophila ortholog Rpt5. Virgin females of Elav-Gal4 or the wild type $2 U$ were crossed to 267 UAS-Rpt5 males. As standard in the field, we used 2 UAS-RNAi lines to rule out the 
medRxiv preprint doi: https://doi.org/10.1101/2021.12.07.21266342; this version posted December 7, 2021. The copyright holder for this preprint (which was not certified by peer review) is the author/funder, who has granted medRxiv a license to display the preprint in perpetuity.

All rights reserved. No reuse allowed without permission.

possibility of insertional or off-target effects. We included genetically appropriate controls with either UAS alone, Gal4 alone or the combination of Gal4 and UAS lines. For behavioural procedures, flies that were $0-2$ days old were set up the day prior to testing and left in an incubator at $23^{\circ} \mathrm{C}$ with $40 \%$ humidity overnight. All testing occurred in an environmental chamber at $25^{\circ} \mathrm{C}$ with $70 \%$ humidity. Flies were given $1 \mathrm{hr}$ to acclimate to the environmental chamber prior to testing. First, Drosophila were trained to associate an odour with a footshock from classical olfactory conditioning as before [39]. Briefly, 100 flies are placed in a training chamber and provided with an odour (odour 1) (either octanol-OCT or methylcyclohexamide- $\mathrm{MCH}$ ) that is presented simultaneously with a foot-shock for 60 seconds. After a brief airing, flies are then provided with a second odour (odour 2) without shock before finally being given a t-maze choice between the two odours for 2 minutes. Flies on each side of the t-maze are then counted. Then, a new set of 100 flies with the same genotype are trained to associate the other odour with a shock. A performance index is then calculated by calculating the ratio of flies avoiding the shocked odour to the total number of flies. For reversal learning, we used a similar approach to previous [40]. Reversal learning uses a similar set up and protocol with the added step of repeating the second odour $45 \mathrm{~s}$ after it was first presented but this time paired with the shock, followed by the first odour without the shock 45 s later, and finally the t-maze choice between the two odours. Statistical analysis was performed using ANOVA and then Tukey tests in JMP (SAS).

\section{Data representation and statistical analyses}

Data are typically mean \pm SEM and analyzed by pair ratio t-test between two groups. All charts and statistical analyses were generated using GraphPad Prism version 8. A p-value $<0.05$ was considered significant. All data are available on request from authors.

\section{Additional materials and methods are available in supplementary information}


medRxiv preprint doi: https://doi.org/10.1101/2021.12.07.21266342; this version posted December 7, 2021. The copyright holder for this preprint (which was not certified by peer review) is the author/funder, who has granted medRxiv a license to display the preprint in perpetuity.

All rights reserved. No reuse allowed without permission.

\section{Results}

\section{Identification of PSMC3 variants}

297 The propositus, Subject \#2, was a female newborn presenting with severe cardiac, gastrointestinal, inflammatory and immune issues. Whole-exome sequencing (WES) highlighted the de novo nonsynonymous c.523A>G p.(Met175Val) variant (GenBank ID: NM_002804.4), predicted to be pathogenic by bioinformatics programs and absent in any public variant databases (gnomAD, >246,000 chromosomes; NHLBI Exome Variant Server, $>13,000$ alleles; Bravo, 125,568 alleles). Via data sharing platform GeneMatcher [41] and direct requests in variants databases whose access was authorized to the University of Washington School of Medicine, a total of 14 distinct rare missense PSMC3 variants could be identified de novo in 22 unrelated children presenting a syndrome characterized by neurodevelopmental delay (NDD) and various congenital anomalies (Table 1).

307

As shown in Figure 1A, most of the PSMC3 substitutions were localized in the "ATPases Associated with diverse cellular Activities" (AAA) domain and predicted to be intolerant to variations (Figure S1). Two distinct regions of the AAA domain were particularly prone to substitutions. The first hotspot was centered on the recurrent variant c.910C>T p.(Arg304Trp) detected in four unrelated children and encompassed variants c.910C>G p.(Arg304Gly, c.915G>T p.(Glu305Asp) and c.929T>C p.(Met310Thr) (Figure 1A). The second region enriched in rare variants [p.(Met259Thr), p.(Met259Val), p.(lle261Thr) -seen six times-, p.(Gly262Arg) and p.(Arg269Pro)] was more N-terminally located (Figure 1A). Importantly, all twelve affected residues were highly conserved across species from mammalians down to fission yeast (Figure 1A).

One major phenotype hallmark of all individuals with PSMC3 variants is the predominance of neurodevelopmental or neuropsychiatric symptoms (Table 2). In more details, apart from

321 Subject \#2, all affected children had developmental delay $(21 / 21 ; 100 \%)$ characterized by speech delay $(18 / 18 ; 100 \%)$ and/or intellectual disability $(15 / 17 ; 88 \%)$, and motor delay 
medRxiv preprint doi: https://doi.org/10.1101/2021.12.07.21266342; this version posted December 7, 2021. The copyright holder for this preprint (which was not certified by peer review) is the author/funder, who has granted medRxiv a license to display the preprint in perpetuity.

All rights reserved. No reuse allowed without permission.

$323(14 / 18 ; 78 \%)$. Brain magnetic resonance imaging highlighted frequent anomalies (11/14; $79 \%)$, whereas abnormal behavior $(9 / 17 ; 53 \%)$ and seizures $(5 / 20 ; 25 \%)$ were inconstant. 9/18 (50\%) individuals experienced growth failure, with feeding difficulties $(8 / 17 ; 47 \%)$. Malformations were frequently observed notably in skeleton $(10 / 14 ; 71 \%$; scoliosis, acetabular dysplasia, brachymetatarsy), heart (10/17; 59\%; ventricular or septal defects, patent ductus arteriosus, pulmonary hypertension and atresia), kidney $(4 / 14 ; 29 \%$; horseshoe shape, pelvicalyceal dilatation, nephrocalcinosis, and multi-cystic dysplastic kidney), and head (microcephaly in 6/16 (38\%); relative to severe macrocephaly in 2/16 $331(13 \%))$. Tumors were noted in $2 / 18$ (11\%) individuals (craniopharyngioma and neuroblastoma). Hearing loss was detected in $8 / 18$ individuals (44\%) and labeled as sensorineural in two and conductive in one of them, respectively. Most children $(17 / 19 ; 89 \%)$ displayed dysmorphic facial features, including notably tall or broad forehead $(7 / 19 ; 37 \%)$, thin upper lip with down-turned corners of mouth $(6 / 19 ; 32 \%)$, abnormal palate $(5 / 19 ; 265 / 19$; $26 \%)$, epicanthal folds $(5 / 19 ; 26 \%)$, and orofacial clefts $(2 / 19 ; 10 \%)$. Computational analysis of facial morphology by GestaltMatcher [42] revealed that facial dysmorphism among the PSMC3 subjects was rather heterogeneous with similarities only observed between patients carrying identical variants (Figure S2).

\section{PSMC3-silenced Drosophila adult flies fail to reverse stimulus contingencies}

342 Given the neuronal nature of the phenotype of PSMC3 subjects, we next sought to address 343 the potential involvement of $P S M C 3$ in cognitive function by evaluating the learning performance of Drosophila fruit flies with a knockdown of PSMC3 (i.e. Rpt5) expression. To this end, we used a standard conditioning of odour-avoidance response in which animals were exposed to two different odours $(\mathrm{OCT}$ or $\mathrm{MCH})$, only one of which resulting in the simultaneous application of a foot-shock (OCT+, $\mathrm{MCH}-$ ), as previously described [39] (Figure 2A). As shown in Figure $\mathbf{2 C}$, pan-neuronal expression of Rpt5 RNAi resulted in no significant differences in learning performance for $\operatorname{Rpt}^{32422}(P=0.6435, N=4)$. Similarly, RNAi 
medRxiv preprint doi: https://doi.org/10.1101/2021.12.07.21266342; this version posted December 7, 2021. The copyright holder for this preprint (which was not certified by peer review) is the author/funder, who has granted medRxiv a license to display the preprint in perpetuity.

All rights reserved. No reuse allowed without permission.

expression in $\mathrm{Rpt}^{53886}$ resulted in normal learning performance $(\mathrm{P}=0.5282, \mathrm{~N}=6)$ as well. We next determined the reversal learning performance of RPT5 silenced flies by training with an initial odour shock pairing (e.g. $\mathrm{OCT}+, \mathrm{MCH}-$ ) immediately followed by training with a reversed odour shock pairing (e.g. OCT-, $\mathrm{MCH}+$ ) (Figure 2B). Strikingly, reversal learning performance was significantly defective with pan-neuronal Rpt5 RNAi expression for $\mathrm{Rpt5}^{32422}(\mathrm{P}<0.0001, \mathrm{~N}=4)$; the three control groups did not significantly differ from each other. RNAi expression also led to defective reversal learning performance for Rpt5 $5^{53886}$ $(P=0.0022, N=6)$; the three control groups once again did not significantly differ from each other (Figure 2B). These data suggest that PSMC3 appears as a prerequisite for the changes in learned associations.

\section{Ectopic expression of PSMC3/Rpt5 or its variants differentially impact neuronal} development

In view of the negative impact of $P S M C 3$ gene silencing on reversal learning, we next asked whether PSMC3 was involved in the regulation of hippocampal neuron dendritic development. To address this point, we ectopically expressed wild-type PSMC3 in murine primary hippocampal neurons prior to neurite length quantification, as previously described [43]. As shown in Figure S3, expression of wild-type PSMC3 at an early developmental time point in vitro (Day In Vitro (DIV) 3) resulted in significantly reduced neurite length of the neurons when fixed 5 days later, at DIV8. These results indicate that increased levels of PSMC3 is damaging for neuronal development. We next sought to determine whether the different PSMC3 variants identified in NDD/ID patients behave differently compared to PSMC3 WT in neurons when ectopically expressed. Interestingly, expression of the p.(Arg304Trp), p.(Glu305Asp) and p.(Glu383Lys) variants resulted in similar neuronal morphological changes as seen with wild-type PSMC3 (Figure S3). By contrast, expression of the p.(Met175Val) variant did not affect neuronal morphology when compared to the empty vector control, and showed significant improvement when compared to wild-type PSMC3. Taken together these results suggest that PSMC3 participates in the regulation of neurite 
medRxiv preprint doi: https://doi.org/10.1101/2021.12.07.21266342; this version posted December 7, 2021. The copyright holder for this preprint (which was not certified by peer review) is the author/funder, who has granted medRxiv a license to display the preprint in perpetuity.

All rights reserved. No reuse allowed without permission.

development and that any alteration of this gene might affect this process positively or negatively.

\section{PSMC3 variants differentially affect the Rpt5 steady-state protein level}

Because missense variants may cause haploinsufficiency by affecting mRNA and/or protein turnover, we next sought to determine the impact of the identified PSMC3 variants on the Rpt5 steady-state expression level. To this end, nine PSMC3 point variants were introduced in the SHSY5Y neuroblastoma cell line and expressed with a fused N-terminal HA tandem repeat prior to western-blot analysis. As shown in Figure $\mathbf{3 A}$, four variants including p.(Arg171Trp), p.(Ala237Val), p.(Met259Val) and p.(lle261Thr) had substantially lower steady-state protein levels than their wild-type counterpart. However, all PSMC3 variants generated equivalent amounts of PSMC3 transcripts in SHSY5Y cells following a 24-h transfection (Figure 3B), indicating that reduced expression at the protein level was due to increased protein turnover and/or decreased translation efficiency. Altogether, these data show that the PSMC3 missense variants identified in NDD/ID subjects do not necessarily behave similarly.

\section{PSMC3 substitutions are predicted to affect inter and intra-molecular interactions} between proteasome subunits

We next attempted to predict the structural consequences of the each of the fourteen PSMC3 substitutions by assessing the localization of the mutated residues in the human $26 \mathrm{~S}$ proteasome structure generated by Dong et al. (PDB-entry code: 6MSK) [44]. As shown in

Figure $3 \mathbf{C}$, most of the affected amino acids emerge within the $\mathrm{N}$-terminal $\alpha / \beta$ domain of PSMC3/Rpt5 with five residues (i.e. Gly262, lle261, Met259, Arg304, Glu305) residing in two loops adjacent to the substrate tunnel pointing towards the center of the AAA-ATPase ring (Figure 3D). Specifically, on one loop, Gly262 is fixed by a main chain hydrogen bond to Glu305, thereby promoting flexibility of the preceding loop containing Met259. Besides, 
medRxiv preprint doi: https://doi.org/10.1101/2021.12.07.21266342; this version posted December 7, 2021. The copyright holder for this preprint (which was not certified by peer review) is the author/funder, who has granted medRxiv a license to display the preprint in perpetuity.

All rights reserved. No reuse allowed without permission.

405 Glu305 itself is held through a salt bridge by Arg308 with its preceding residue Arg304 406 involved in a polar network stabilizing the neighbouring loop (Figure S4). Because these six 407 residues stabilize or are part of the tertiary structure of the loops, any alteration of these amino acids is predicted to affect substrate trafficking, as well as interactions with other AAAATPase subunits. As shown in Figure S4, the Ala237Val variant is more difficult to classify and does not reveal itself on structural level at first sight. However, one cannot exclude that the slight increase in residue size at position 237 might lead to structural changes. Indeed, our overexpression assays in SHSY5Y cells suggest that such substitution does affect sidechain packing and protein stability (Figure $3 \mathrm{~A}$ ). The p.(Glu383Lys) missense variant is the only substitution lying within the C-terminal a-helical domain of PSMC3/Rpt5 adjacent to the 19S-20S interface. Interestingly, Glu383 holds GIn166 from the PSMA1/a6 subunit for polar interactions with both of the Arg169 and Arg386 residues (Figure 3E). Variant of the negatively charged Glu383 to a positively charged Lys383 is therefore predicted to disrupt such hydrogen bond network and affect the association of the 19S complex with the $20 \mathrm{~S}$ core particle. Interestingly, Glu287 is located in close proximity of the ATP binding site within PSMC3/Rpt5 (Figure S4) and its substitution into Gln287 presumably generates additional polar bonds with Asn333 likely to affect ATP binding and/or hydrolysis. As illustrated in Figure S5, Arg171 is positioned at the PSMC3/Rpt5-PSMC2/Rpt1 interface and is part of a polar network involving the neighboring Asp169 and Asn258 residues. As such, the substitution of positively charged arginine to hydrophobic tryptophan at this position is predicted to disrupt these interactions, and a fortiori to affect the contact between the two subunits (Figure S5). As for the Met175Val residue, its change to Val175 results in the loss of a polarized thiol group and hydrophilic environment is likely to destabilize the tertiary structure of this protein region (Figure S5). Taken together, these data suggest that the complex 26S proteasome structure could be strongly affected by the identified PSMC3/Rpt5 missense variants through distinct mechanisms including substrate translocation or 19SATPase-interaction with the $20 \mathrm{~S}$ particle. 
medRxiv preprint doi: https://doi.org/10.1101/2021.12.07.21266342; this version posted December 7, 2021. The copyright holder for this preprint (which was not certified by peer review) is the author/funder, who has granted medRxiv a license to display the preprint in perpetuity.

All rights reserved. No reuse allowed without permission.

433 PSMC3 variants differentially impact proteasome assembly in NDD/ID subjects

434 To further address the pathogenicity of the PSMC3 variants, T cells from Subjects \#12, \#17

435 and \#20, were next analyzed by SDS-PAGE/western-blotting for their proteasome contents.

436 As shown in Figure 4A, the expression levels of the proteasome a-subunits (i.e. a7) and

437 PA28- $\alpha$ did not significantly vary between controls and index cases. Likewise, the abundance

438 of the $19 S$ subunits (i.e. Rpt5 and Rpn5) in mutant T cells was quite comparable to that

439 detected in their control counterparts. Most importantly, none of PSMC3 variant T cells

440 showed reduced expression of the Rpt5 full-length protein, suggesting that proteasome

441 dysfunction in these affected individuals was not due to haploinsufficiency.

442

443 T cells from affected individuals and relative controls (i.e. father and/or mother) were next 444 analyzed for proteasome complex formation and activity by in-gel fluorescence or western 445 blotting on native PAGE. As shown in Figure 4B, the chymotrypsin-like activity of the 26S 446 and 20S proteasome complexes was reduced in Subjects \#17 and \#20, respectively, while it was mostly unchanged in Subject \#12. Subsequent western-blot analysis revealed that the decreased 20S activity observed in Subject \#20 was due to a decreased pool of her 20SPA28 complexes, as determined by reduced band intensity for the $a 6$ and PA28 proteins. In

a similar fashion, a diminished expression of the a6, PSMC3/Rpt5 and PSMD12/Rpn5 subunits was observed in the 26S proteasomes of Subject \#17 (Figure 4B), indicating that the decline in 265 activity detected in this patient was likely to be attributed to decreased amounts of $26 \mathrm{~S}$ complexes. However, the $20 \mathrm{~S}$ and $26 \mathrm{~S}$ proteasome pools of Subject \#12 did not substantially vary when compared to those of his related control (Figure 4B). Altogether, these data indicate that both of the p.(Arg304Trp) and p.(Glu305Asp) PSMC3/Rpt5 variants critically affect $20 S$ and/or $26 S$ proteasome assembly in individuals with NDD/ID, while the p.(Gly262Arg) variant has little impact in this process. 
medRxiv preprint doi: https://doi.org/10.1101/2021.12.07.21266342; this version posted December 7, 2021. The copyright holder for this preprint (which was not certified by peer review) is the author/funder, who has granted medRxiv a license to display the preprint in perpetuity.

All rights reserved. No reuse allowed without permission.

461 To better understand the cellular consequences of PSMC3 loss-of-function, we next

462 performed a mass spectrometry (MS)-based comparative analysis of the proteome of

463 Subjects \#16 and \#20 (p.Arg304Trp and p.Glu305Asp, respectively) to that of their wild-type

464 counterparts. As shown in Figure 5, our data identified a protein biomarker signature

465 consisting of seventeen ribosomal proteins of the small 40S (i.e. RPS) or large 60S (i.e. RPL)

466 ribosomal subunits which were specifically upregulated in both investigated patients. This

467 suggests that mRNA translation is a major affected pathway upon PSMC3 loss-of-function, a

468 notion which is further supported by the view that components of the mRNA processing

469 machinery such as CELF1, LSM1, SSU72 and ITPA are also differentially expressed across

470 patients and controls (Figure 5). Other notable proteins whose abundances vary in PSMC3

471 subjects include components of the immune system such as MX1 -a typical interferon (IFN)-

472 stimulated gene product- and the a-chain of the IL3 receptor (IL3RA). Interestingly, these

473 proteins are regulated in opposite directions with both patients exhibiting higher amounts of

474 MX1 but reduced levels of IL3RA (Figure 5). Our analysis further revealed that PSMC3 loss-

475 of-function was also associated with increased protein levels of the $\mathrm{H} 1.5$ and $\mathrm{H} 1.2$ linker

476 histone $\mathrm{H} 1$ variants, a finding that may point to a distinct chromatin regulation in these

477 patients. Collectively, these data suggest that patients with PSMC3 variants exhibit

478 alterations in basic cellular processes including mRNA translation, immune signaling and

479 chromatin remodeling.

480

481

\section{PSMC3 variants cause proteotoxic stress in patient cells}

482 Control and subject $T$ cells were next analyzed for their content in ubiquitin-protein 483 conjugates by western-blotting. As shown in Figure 6A, all four investigated patients 484 exhibited typical features of unbalanced protein homeostasis, as evidenced by increased 485 accumulation of ubiquitin-modified species when compared to their respective related 486 controls. 
medRxiv preprint doi: https://doi.org/10.1101/2021.12.07.21266342; this version posted December 7, 2021. The copyright holder for this preprint (which was not certified by peer review) is the author/funder, who has granted medRxiv a license to display the preprint in perpetuity.

All rights reserved. No reuse allowed without permission.

Proteotoxic stress is known to induce the unfolded and integrated stress response (i.e. UPR and ISR, respectively) [26]. To address this point, we monitored in both control and variant T cells from Subjects \#12, \#16, \#17 and \#20 the expression level of the GRP94 chaperone protein whose upregulation is understood to be a major hallmark of the UPR [45]. Indeed, as shown in Figure 6A, all four investigated PSMC3 subjects exhibited increased steady-state expression levels of GRP94 when compared to their respective related controls, indicating that their T cells suffer from ER stress. However, the activation of the UPR was only partial, as the phosphorylation/activation status of two other UPR markers, namely IRE1 and elF2a, was not changed between controls and PSMC3 subjects (Figure 6A). The failure to detect increased phosphorylated elF2a is intriguing considering the fact that one its major upstream kinases, protein kinase $R(P K R)$, was consistently activated in all subjects (Figure 6A). It may however be easily explained by the observation that both elF2 $\alpha$ phosphatases GADD34 and CReP were consistently up-regulated across all four patients.

Interestingly, T cells with PSMC3 variants were also endowed with increased steady-state expression levels of LC3-II (Figure 6B), suggesting that the inability of these cells to eliminate ubiquitin-protein aggregates cells via their $26 \mathrm{~S}$ proteasomes triggers a compensatory mechanism mediated by activation of the autophagy system. Consistently, the mitochondrial proteins PINK1 and Bnip3L/NIX were found to be decreased in all four NDD/ID subjects with PSMC3 variants (Figure 6B), supporting the notion that selective autophagic processes including mitophagy were persistently activated upon PSMC3 disruption. Because proteasome impairment typically results in the release of the TCF11/Nrf1 transcription factor from the ER membrane [46, 47], we next sought to determine whether TCF11/Nrf1 was processed in NDD/ID affected individuals. However, no difference in the TCF11/Nrf1 processing pattern could be detected between controls and PSMC3 subjects (Figure 6B), suggesting that PSMC3 variants associated with NDD/ID do not initiate the TCF11/Nrf1 signaling pathway. 
medRxiv preprint doi: https://doi.org/10.1101/2021.12.07.21266342; this version posted December 7, 2021. The copyright holder for this preprint (which was not certified by peer review) is the author/funder, who has granted medRxiv a license to display the preprint in perpetuity.

All rights reserved. No reuse allowed without permission.

516 T cells isolated from patients harboring PSMC3 variants exhibit a typical type I IFN

\section{7 signature}

518 Because proteasome loss-of-functions caused by variants in genes of $20 \mathrm{~S}$ core particle 519 subunits result in the generation of a typical type I IFN response [32], we next sought to 520 determine whether alterations in the PSMC3 gene would induce interferonopathies as well.

521 To this end, we undertook a comparative examination of the mRNA levels of 750 predefined 522 immunological relevant genes in T cells from PSMC3 subjects and relative controls (father 523 and/or mother) using the NanoString ${ }^{\circledR}$ nCounter platform. Interestingly, a total of 30 524 differentially expressed genes could be identified including 11 interferon-stimulated genes 525 (ISG) which were specifically upregulated in all NDD/ID patients (Figure 7A), suggesting that 526 PSMC3 loss-of-function is associated with a type I IFN response. Besides, our transcriptomic 527 analysis of control and subject T cells further revealed that PSMC3 disruption resulted in the upregulation of genes of the notch signaling pathway such as NOTCH2 and JAG2 involved in neurodevelopment [48] (Figure 7A).

530

531 To validate the type I IFN gene signature unraveled by our omics profiling of the PSMC3 532 subjects, we next evaluated the transcription rate of six ISG (IFI27, IFI44L, IFIT1, ISG15, 533 RSAD2 and IFI44) by quantitative PCR in T cells isolated from these four families with 534 PSMC3 missense variants. Strikingly, as shown in Figure 7B, all four affected children 535 (Subjects \#12, \#16, \#17 and \#20) exhibited much higher ISG expression levels than their 536 parents (father and/or mother) used as controls. Calculation of the median fold change of the 537 six ISG revealed that a minimum and significant increase of 2.23-fold was detected in all 538 PSMC3 index cases when compared to their respective controls. The strongest type I IFN 539 signature was observed in Subject \#17 whose ISG were upregulated by approximately 75540 and 12-fold when compared to her father and mother, respectively. Subjects \#12, \#16 and 541 \#20 exhibited a milder type I IFN induction characterized by a 2-to 6-fold greater amount of 542 ISG transcripts than their respective controls. Among the six ISG tested, IFIT1, and IFI44L 
medRxiv preprint doi: https://doi.org/10.1101/2021.12.07.21266342; this version posted December 7, 2021. The copyright holder for this preprint

(which was not certified by peer review) is the author/funder, who has granted medRxiv a license to display the preprint in perpetuity.

All rights reserved. No reuse allowed without permission.

543 were the genes which underwent the most pronounced upregulation in all four NDD/ID

544 affected individuals.

545

546 To strengthen our view that NDD/ID affected individuals with PSMC3 missense variants

547 develop an interferonopathy, we next calculated and compared the IFN scores of both

548 PSMC3 subjects and their related controls to those of $\mathrm{T}$ cells isolated from six healthy

549 donors. As shown in Figure 8, three of the NDD/ID related controls had an IFN score slightly

550 above the cut-off value of 2.466 defined by Rice et al. to be abnormal [49]. However, the IFN

551 scores of all related and unrelated controls remain significantly lower than those of the four

552 tested NDD/ID patients, thereby confirming that these PSMC3 variants were associated with

553 enhanced type I IFN signaling.

554

555 
medRxiv preprint doi: https://doi.org/10.1101/2021.12.07.21266342; this version posted December 7, 2021. The copyright holder for this preprint (which was not certified by peer review) is the author/funder, who has granted medRxiv a license to display the preprint in perpetuity.

All rights reserved. No reuse allowed without permission.

Discussion

557 Here, we report fourteen missense variants in the PSMC3 gene in twenty-two unrelated

558 individuals with NDD (Figure 1, Tables 1 and 2) which clearly identify the 19S AAA-ATPase

559 proteasome subunit PSMC3/Rpt5 as a critical protein for the development of the central

560 nervous system (CNS). This notion is in line with previous reports showing that conditional

561 inactivation of other 19S proteasome subunits (i.e. PSMC1/Rpt2 and PSMC4/Rpt3) in mice

562 results in severe neuronal phenotypes with features of neurodegeneration and locomotor

563 dysfunction $[50,51]$.

564

565 Recently, a homozygous deep intronic variant creating a cryptic exon in the PSMC3 gene 566 was linked to a familial recessive neurosensory syndrome [52]. However, given their distinct 567 modes of inheritance and pathogenesis, we believe that this recessive disorder observed in a 568 single family and the dominant one, which we describe here in multiple families, are two 569 different clinical entities. This assumption is substantiated by the fairly partial and inconstant 570 overlap of disease phenotypes as neither cataract, nor neuropathy or similar cutaneous 571 features -which are the hallmarks of the recessive syndrome- were observed in patients with 572 NDD/ID reported in the present series. This notion is also supported by the fact that, unlike 573 the familial recessive neurosensory syndrome described by Kroll et al., the dominant NDD/ID 574 identified in this manuscript is not characterized by constitutive processing of TCF11/Nrf1 575 (Figure 6B).

576

577 Cognitive flexibility is an important aspect of typical brain function which allows adaptation to 578 both physical and social environmental changes [53, 54]. This may be assessed by 579 evaluating reversal learning performance, a process which was identified several years ago 580 in Drosophila adult flies [40] and whose dysfunction has been associated with the 581 pathogenesis of various neuropsychiatric disorders [55-59]. Strikingly, while PSMC3 gene582 silencing in flies had no discernible effect on learning performance, it severely compromised 583 reversal learning (Figure 2). Interestingly, although proteasomes have been shown to 
medRxiv preprint doi: https://doi.org/10.1101/2021.12.07.21266342; this version posted December 7, 2021. The copyright holder for this preprint (which was not certified by peer review) is the author/funder, who has granted medRxiv a license to display the preprint in perpetuity.

All rights reserved. No reuse allowed without permission.

584 regulate long-term potentiation (LTP) [60, 61], their involvement in reversal learning was not 585 known. Our data clearly identify PSMC3/Rpt5 as a key regulator of this process whose 586 molecular landscape was initially limited to a few molecules related to the cytoskeleton and 587 GABAergic system [62-64]. Additional evidence in favour of a critical role of PSMC3/Rpt5 in behavioural flexibility emerges from our experiments in primary hippocampal neurons showing that PSMC3/Rpt5 overexpression affects dendrite growth (Figure S4). One could argue that the adverse effects of PSMC3/Rpt5 on this process might be due to extraproteasome functions as a consequence of an excess of "free" subunit following transfection. However, our investigations on patient T cells clearly show that PSMC3 missense variants are associated with an increased accumulation of ubiquitin-modified proteins (Figure 6A). This indicates that these alterations give rise to proteasome loss-of-function variants associated with perturbed protein homeostasis. Interestingly, our proteomic analysis revealed that subject $T$ cells carrying PSMC3 variants were particularly enriched with ribosomal proteins such as RPL4, RPL6, RPL7A and RPL7 (Figure 5 and Table 3). These proteins may be specifically targeted for degradation in these affected individuals and that their accumulation occurs as a consequence of impaired intracellular protein clearance. Consistent with this notion, proteasome inhibition has been recently shown to result in the aggregation of ubiquitin-modified ribosomal proteins [65]. Our data therefore support the recent view that ribosome dysregulation defines a key feature of NDD/ID phenotypes $[66,67]$ and the concept of translational arrest upon proteotoxic stress via the action of elF2a kinases (Figure 5A).

605

606 One key finding is the observation that NDD/ID subjects with PSMC3 variants generate a 607 type I IFN gene signature with elevated expression of typical ISG including IFIT1, IFI27, IFI44, IFI44L, ISG15 and RSAD2 (Figures 7 and 8). Although it is well-established that proteasome loss-of-functions variants cause interferonopathies in CANDLE/PRAAS subjects,

610 these alterations were long restricted to subunits of the $20 \mathrm{~S}$ core particle and/or proteasome assembly factors so far [29-35]. It was only recently that pathogenic variants in subunits of 
medRxiv preprint doi: https://doi.org/10.1101/2021.12.07.21266342; this version posted December 7, 2021. The copyright holder for this preprint (which was not certified by peer review) is the author/funder, who has granted medRxiv a license to display the preprint in perpetuity.

All rights reserved. No reuse allowed without permission.

612 the 19S regulatory particle, namely PSMD12, were reported to engage constitutive type I IFN 613 signaling in patients with Stankiewicz-Isidor syndrome (STISS) (in press), a NDD disorder 614 sharing levels of similarities with the one described in this manuscript. Intriguingly, although both CANDLE/PRAAS subjects and NDD/ID individuals with PSMD12 or PSMC3 variants carry genomic alterations that affect the same multi-subunit enzyme (i.e. $26 \mathrm{~S}$ proteasome),

617 their clinical phenotypes do not entirely overlap. Notably, NDD/ID subjects with PSMC3 variants failed to develop recurrent fever, lipodystrophy and/or skin lesions which are usually detected in CANDLE/PRAAS subjects (Table 1). One could argue that such differences may reflect distinct localizations of the affected subunits within the $26 \mathrm{~S}$ proteasome complex, thereby suggesting that alterations of the $19 \mathrm{~S}$ regulatory particle promote the generation of NDD/ID, while those of the $20 \mathrm{~S}$ core particle and/or assembly chaperones favor the development a CANDLE/PRAAS phenotype. This assumption is however challenged by the fact that PSMB1/ $\beta 6$ variants of the $20 S$ core particle lead to the acquisition of neuronal phenotype very similar to that seen in NDD/ID subjects with PSMC3 variants [27]. The lack of systemic autoinflammation in NDD/ID subjects mounting a constitutive type I IFN response may seem surprising at first sight, but it is not totally unexpected, since this inconsistency is found in other neurodevelopmental disorders including Aicardi-Goutières [68,69] and Down syndromes $[70,71]$. This is particularly well exemplified in Down syndrome patients who, like NDD/ID subjects with PSMC3 dominant variants, exhibit a constitutive activation of type I IFN signaling $[72,73]$. To what extent type I IFN actively contributes to the pathogenesis of these disorders remains to be fully determined, even though a growing body of evidence supports the notion that IFN has detrimental effects on CNS function [74-77] and/or stem cell function and differentiation $[78,79]$.

635

Because proteasome dysfunction typically engages stress responses involving compensatory mechanisms such as autophagy [80], the integrated stress response (ISR) and the unfolded protein response (UPR) [26, 81], we reasoned that the sterile type I IFN response detected in subjects with $P S M C 3$ variants might be due to sustained activation of 
medRxiv preprint doi: https://doi.org/10.1101/2021.12.07.21266342; this version posted December 7, 2021. The copyright holder for this preprint (which was not certified by peer review) is the author/funder, who has granted medRxiv a license to display the preprint in perpetuity.

All rights reserved. No reuse allowed without permission.

640 either one of these pathways. As anticipated, high levels of autophagy and ER stress were

641 detected in NDD/ID affected individuals, as evidenced by increased expression of the LC3-II

642 and GRP94 proteins (Figure 6A). Both PINK1 and NIX mitochondrial proteins were found to

643 be decreased in NDD/ID subjects (Figure 6B), suggesting that PSMC3 variants increase

644 autophagy-driven elimination of mitochondria (i.e. mitophagy). This observation supports the

645 growing consensus that mitochondria dysfunction is a key determinant of the pathogenesis of

646 neurodevelopment [82]. Besides, the activation status of PKR, a protein of the ISR that

647 intersects with the UPR [83], was substantially increased in all investigated PSMC3 subjects.

648 Both ISR and UPR have the ability to counterbalance proteotoxic stress by inducing a global

649 translational arrest via elF2a phosphorylation. This is accompanied by concomitant

650 accumulation of non-translated mRNAs, the formation of stress granules recruiting different

651 RNA species and RNA processing enzymes, and IRE-1 dependent mRNA decay (RIDD)

652 [84]. Although PKR typically responds to viral double stranded RNA [85], it also may undergo

653 activation under sterile conditions upon different stresses including ER-stress involving PKR-

654 associated activator PACT and its modulator TRBP, a protein required for micro RNA

655 biogenesis [86-88]. Both, PACT and TRBP were observed to be increased in subject's cells

656 along with a couple of RNA-processing factors in our omics analysis strongly indicating that

657 PKR activation occurs via uncontrolled RNA processing. The mechanisms by which PSMC3

658 variants activate PKR in NDD/ID affected individuals remain unclear, but our data open the

659 possibility that PKR may sense a broader spectrum of danger signals than initially assumed,

660 including perturbations of protein homeostasis. This concept is in line with the observation

661 that activated PKR was found in the CNS of subjects with neurodegenerative diseases [89-

662 92] and that neurodegeneration is associated with neuroinflammation [93, 94]. Altogether,

663 our work demonstrates that heterozygous PSMC3 dominant variants result in a

664 neurodevelopmental syndrome associated with a specific type I IFN gene signature.

665 
medRxiv preprint doi: https://doi.org/10.1101/2021.12.07.21266342; this version posted December 7, 2021. The copyright holder for this preprint (which was not certified by peer review) is the author/funder, who has granted medRxiv a license to display the preprint in perpetuity. All rights reserved. No reuse allowed without permission.

667 This work was supported by the German Research Foundation (SFBTR167, RGT2719-PRO 668 project B4) to EK, E-Rare project GENOMIT (Austrian Science Fund FWF, 14695-B) to JAM, 669 in part, by US National Institutes of Health (NIH) grants (R01MH101221) and a grant from 670 the Simons Foundation (SFARI \#608045) to E.E.E.; E.E.E. is an investigator of the Howard 671 Hughes Medical Institute.

672 
medRxiv preprint doi: https://doi.org/10.1101/2021.12.07.21266342; this version posted December 7, 2021. The copyright holder for this preprint (which was not certified by peer review) is the author/funder, who has granted medRxiv a license to display the preprint in perpetuity.

All rights reserved. No reuse allowed without permission.

\section{References}

1. Tanaka, K., T. Mizushima, and Y. Saeki, The proteasome: molecular machinery and pathophysiological roles. Biol Chem, 2012. 393(4): p. 217-34.

2. Collins, G.A. and A.L. Goldberg, The Logic of the 265 Proteasome. Cell, 2017. 169(5): p. 792806.

3. Toyama, B.H. and M.W. Hetzer, Protein homeostasis: live long, won't prosper. Nat Rev Mol Cell Biol, 2013. 14(1): p. 55-61.

4. Goloubinoff, P., Mechanisms of protein homeostasis in health, aging and disease. Swiss Med Wkly, 2016. 146: p. w14306.

5. Seifert, U., et al., Immunoproteasomes preserve protein homeostasis upon interferon-induced oxidative stress. Cell, 2010. 142(4): p. 613-24 PMID: 20723761.

6. Kruger, E. and P.M. Kloetzel, Immunoproteasomes at the interface of innate and adaptive immune responses: two faces of one enzyme. Curr Opin Immunol, 2012. 24(1): p. 77-83.

7. Pickart, C.M., Mechanisms underlying ubiquitination. Annu Rev Biochem, 2001. 70: p. 503-33.

8. Demartino, G.N. and T.G. Gillette, Proteasomes: machines for all reasons. Cell, 2007. 129(4): p. 659-62.

9. Pickart, C.M. and D. Fushman, Polyubiquitin chains: polymeric protein signals. Curr Opin Chem Biol, 2004. 8(6): p. 610-6.

10. Pickart, C.M., Back to the future with ubiquitin. Cell, 2004. 116(2): p. 181-90.

11. Tanaka, K., The proteasome: overview of structure and functions. Proc Jpn Acad Ser B Phys Biol Sci, 2009. 85(1): p. 12-36.

12. Dahlmann, B., Mammalian proteasome subtypes: Their diversity in structure and function. Arch Biochem Biophys, 2016. 591: p. 132-40.

13. Finley, D., Recognition and processing of ubiquitin-protein conjugates by the proteasome. Annu Rev Biochem, 2009. 78: p. 477-513.

14. Benaroudj, N., et al., The unfolding of substrates and ubiquitin-independent protein degradation by proteasomes. Biochimie, 2001. 83(3-4): p. 311-8.

15. Kisselev, A.F., W.A. van der Linden, and H.S. Overkleeft, Proteasome inhibitors: an expanding army attacking a unique target. Chem Biol, 2012. 19(1): p. 99-115.

16. Finley, D., X. Chen, and K.J. Walters, Gates, Channels, and Switches: Elements of the Proteasome Machine. Trends Biochem Sci, 2016. 41(1): p. 77-93.

17. Ebstein, F., et al., Emerging roles of immunoproteasomes beyond MHC class I antigen processing. Cell Mol Life Sci, 2012. 69(15): p. 2543-58 PMID: 22382925.

18. Strehl, B., et al., Interferon-gamma, the functional plasticity of the ubiquitin-proteasome system, and MHC class I antigen processing. Immunol Rev, 2005. 207: p. 19-30.

19. Shin, E.C., et al., Proteasome activator and antigen-processing aminopeptidases are regulated by virus-induced type I interferon in the hepatitis $C$ virus-infected liver. J Interferon Cytokine Res, 2007. 27(12): p. 985-90.

20. Tomko, R.J., Jr., et al., Heterohexameric ring arrangement of the eukaryotic proteasomal ATPases: implications for proteasome structure and assembly. Mol Cell, 2010. 38(3): p. 393403.

21. Smith, D.M., et al., Docking of the proteasomal ATPases' carboxyl termini in the $20 \mathrm{~S}$ proteasome's alpha ring opens the gate for substrate entry. Mol Cell, 2007. 27(5): p. 731-44.

22. Greene, E.R., K.C. Dong, and A. Martin, Understanding the 265 proteasome molecular machine from a structural and conformational dynamics perspective. Curr Opin Struct Biol, 2020. 61: p. 33-41.

23. Greene, E.R., et al., Specific lid-base contacts in the $26 \mathrm{~s}$ proteasome control the conformational switching required for substrate degradation. Elife, 2019. 8.

24. Verma, R., et al., Role of Rpn11 metalloprotease in deubiquitination and degradation by the 265 proteasome. Science, 2002. 298(5593): p. 611-5. 
25. Brehm, A. and E. Kruger, Dysfunction in protein clearance by the proteasome: impact on autoinflammatory diseases. Semin Immunopathol, 2015. 37(4): p. 323-33 PMID: 25963519.

26. Ebstein, F., et al., Contribution of the Unfolded Protein Response (UPR) to the Pathogenesis of Proteasome-Associated Autoinflammatory Syndromes (PRAAS). Front Immunol, 2019. 10: p. 2756 PMID: 31827472.

27. Ansar, M., et al., Biallelic variants in PSMB1 encoding the proteasome subunit beta 6 cause impairment of proteasome function, microcephaly, intellectual disability, developmental delay and short stature. Hum Mol Genet, 2020. 29(7): p. 1132-1143.

28. Agarwal, A.K., et al., PSMB8 encoding the beta5i proteasome subunit is mutated in joint contractures, muscle atrophy, microcytic anemia, and panniculitis-induced lipodystrophy syndrome. Am J Hum Genet, 2010. 87(6): p. 866-72.

29. Arima, K., et al., Proteasome assembly defect due to a proteasome subunit beta type 8 (PSMB8) mutation causes the autoinflammatory disorder, Nakajo-Nishimura syndrome. Proc Natl Acad Sci U S A, 2011. 108(36): p. 14914-9.

30. Kitamura, A., et al., $A$ mutation in the immunoproteasome subunit PSMB8 causes autoinflammation and lipodystrophy in humans. J Clin Invest, 2011. 121(10): p. 4150-60.

31. Liu, Y., et al., Mutations in proteasome subunit beta type 8 cause chronic atypical neutrophilic dermatosis with lipodystrophy and elevated temperature with evidence of genetic and phenotypic heterogeneity. Arthritis Rheum, 2012. 64(3): p. 895-907.

32. Brehm, A., et al., Additive loss-of-function proteasome subunit mutations in CANDLE/PRAAS patients promote type IIFN production. J Clin Invest, 2015. 125(11): p. 4196-211.

33. Poli, M.C., et al., Heterozygous Truncating Variants in POMP Escape Nonsense-Mediated Decay and Cause a Unique Immune Dysregulatory Syndrome. Am J Hum Genet, 2018. 102(6): p. 1126-1142.

34. de Jesus, A.A., et al., Novel proteasome assembly chaperone mutations in PSMG2/PAC2 cause the autoinflammatory interferonopathy CANDLE/PRAAS4. J Allergy Clin Immunol, 2019. 143(5): p. 1939-1943 e8.

35. Sarrabay, G., et al., PSMB10, the last immunoproteasome gene missing for PRAAS. J Allergy Clin Immunol, 2019.

36. Kury, S., et al., De Novo Disruption of the Proteasome Regulatory Subunit PSMD12 Causes a Syndromic Neurodevelopmental Disorder. Am J Hum Genet, 2017. 100(2): p. 352-363.

37. Fonteneau, J.F., et al., Generation of high quantities of viral and tumor-specific human CD4+ and CD8+ T-cell clones using peptide pulsed mature dendritic cells. J Immunol Methods, 2001. 258(1-2): p. 111-26.

38. Bolduc, F.V., et al., Excess protein synthesis in Drosophila fragile X mutants impairs long-term memory. Nat Neurosci, 2008. 11(10): p. 1143-5.

39. Tully, T. and W.G. Quinn, Classical conditioning and retention in normal and mutant Drosophila melanogaster. J Comp Physiol A, 1985. 157(2): p. 263-77.

40. Tully, T., et al., Genetic dissection of memory formation in Drosophila melanogaster. Cold Spring Harb Symp Quant Biol, 1990. 55: p. 203-11.

41. Sobreira, N., et al., GeneMatcher: a matching tool for connecting investigators with an interest in the same gene. Hum Mutat, 2015. 36(10): p. 928-30.

42. Hsieh, T.C., et al., GestaltMatcher: Overcoming the limits of rare disease matching using facial phenotypic descriptors. medRxiv, 2021. medRxiv 2020.12.28.20248193.

43. Kury, S., et al., De Novo Mutations in Protein Kinase Genes CAMK2A and CAMK2B Cause Intellectual Disability. Am J Hum Genet, 2017. 101(5): p. 768-788 PMID: 29100089.

44. Dong, Y., et al., Cryo-EM structures and dynamics of substrate-engaged human 265 proteasome. Nature, 2019. 565(7737): p. 49-55.

45. Marzec, M., D. Eletto, and Y. Argon, GRP94: An HSP9O-like protein specialized for protein folding and quality control in the endoplasmic reticulum. Biochim Biophys Acta, 2012. 1823(3): p. 774-87. 
46. Steffen, J., et al., Proteasomal degradation is transcriptionally controlled by TCF11 via an ERAD-dependent feedback loop. Mol Cell, 2010. 40(1): p. 147-58 PMID: 20932482.

47. Radhakrishnan, S.K., et al., Transcription factor Nrf1 mediates the proteasome recovery pathway after proteasome inhibition in mammalian cells. Mol Cell, 2010. 38(1): p. 17-28.

48. Kostyszyn, B., et al., Distribution of presenilin 1 and 2 and their relation to Notch receptors and ligands in human embryonic/foetal central nervous system. Brain Res Dev Brain Res, 2004. 151(1-2): p. 75-86.

49. Rice, G.I., et al., Assessment of Type I Interferon Signaling in Pediatric Inflammatory Disease. J Clin Immunol, 2017. 37(2): p. 123-132 PMID: 27943079.

50. Bedford, L., et al., Depletion of 265 proteasomes in mouse brain neurons causes neurodegeneration and Lewy-like inclusions resembling human pale bodies. J Neurosci, 2008. 28(33): p. 8189-98.

51. Tashiro, Y., et al., Motor neuron-specific disruption of proteasomes, but not autophagy, replicates amyotrophic lateral sclerosis. J Biol Chem, 2012. 287(51): p. 42984-94.

52. Kroll-Hermi, A., et al., Proteasome subunit PSMC3 variants cause ne urosensory syndrome combining deafness and cataract due to proteotoxic stress. EMBO Mol Med, 2020. 12(7): p. e11861.

53. Reed, P., H. Watts, and R. Truzoli, Flexibility in young people with autism spectrum disorders on a card sort task. Autism, 2013. 17(2): p. 162-71.

54. Leung, R.C. and K.K. Zakzanis, Brief report: cognitive flexibility in autism spectrum disorders: a quantitative review. J Autism Dev Disord, 2014. 44(10): p. 2628-45.

55. Swainson, R., et al., Probabilistic learning and reversal deficits in patients with Parkinson's disease or frontal or temporal lobe lesions: possible adverse effects of dopaminergic medication. Neuropsychologia, 2000. 38(5): p. 596-612.

56. Remijnse, P.L., et al., Reduced orbitofrontal-striatal activity on a reversal learning task in obsessive-compulsive disorder. Arch Gen Psychiatry, 2006. 63(11): p. 1225-36.

57. Finger, E.C., et al., Abnormal ventromedial prefrontal cortex function in children with psychopathic traits during reversal learning. Arch Gen Psychiatry, 2008. 65(5): p. 586-94.

58. Leeson, V.C., et al., Discrimination learning, reversal, and set-shifting in first-episode schizophrenia: stability over six years and specific associations with medication type and disorganization syndrome. Biol Psychiatry, 2009. 66(6): p. 586-93.

59. Izquierdo, A. and J.D. Jentsch, Reversal learning as a measure of impulsive and compulsive behavior in addictions. Psychopharmacology (Berl), 2012. 219(2): p. 607-20.

60. Smolen, P., D.A. Baxter, and J.H. Byrne, Paradoxical LTP maintenance with inhibition of protein synthesis and the proteasome suggests a novel protein synthesis requirement for early LTP reversal. J Theor Biol, 2018. 457: p. 79-87.

61. Dong, $\mathrm{C}$., et al., Proteasome modulates positive and negative translational regulators in longterm synaptic plasticity. J Neurosci, 2014. 34(9): p. 3171-82.

62. Wilhelmsson, U., et al., The role of GFAP and vimentin in learning and memory. Biol Chem, 2019. 400(9): p. 1147-1156.

63. Hausrat, T.J., et al., Radixin regulates synaptic GABAA receptor density and is essential for reversal learning and short-term memory. Nat Commun, 2015. 6: p. 6872.

64. DePoy, L.M. and S.L. Gourley, Synaptic Cytoskeletal Plasticity in the Prefrontal Cortex Following Psychostimulant Exposure. Traffic, 2015. 16(9): p. 919-40.

65. Sung, M.K., et al., Ribosomal proteins produced in excess are degraded by the ubiquitinproteasome system. Mol Biol Cell, 2016. 27(17): p. 2642-52.

66. Hetman, M. and L.P. Slomnicki, Ribosomal biogenesis as an emerging target of neurodevelopmental pathologies. J Neurochem, 2019. 148(3): p. 325-347.

67. Bourque, D.K., et al., A de novo mutation in RPL10 causes a rare X-linked ribosomopathy characterized by syndromic intellectual disability and epilepsy: $A$ new case and review of the literature. Eur J Med Genet, 2018. 61(2): p. 89-93. 
medRxiv preprint doi: https://doi.org/10.1101/2021.12.07.21266342; this version posted December 7, 2021. The copyright holder for this preprint (which was not certified by peer review) is the author/funder, who has granted medRxiv a license to display the preprint in perpetuity.

All rights reserved. No reuse allowed without permission.

826 68. Crow, Y.J. and N. Manel, Aicardi-Goutieres syndrome and the type I interferonopathies. Nat 
medRxiv preprint doi: https://doi.org/10.1101/2021.12.07.21266342; this version posted December 7, 2021. The copyright holder for this preprint (which was not certified by peer review) is the author/funder, who has granted medRxiv a license to display the preprint in perpetuity.

All rights reserved. No reuse allowed without permission.

877 92. Chukwurah, E., et al., A tale of two proteins: PACT and PKR and their roles in inflammation. FEBS J, 2021.

879 93. Muzio, L., A. Viotti, and G. Martino, Microglia in Neuroinflammation and Neurodegeneration: From Understanding to Therapy. Front Neurosci, 2021. 15: p. 742065.

881

882

94. Ahmed, M.M., et al., Innate Immune System Activation and Neuroinflammation in Down Syndrome and Neurodegeneration: Therapeutic Targets or Partners? Front Aging Neurosci, 2021. 13: p. 718426.

884 
Table 1. Main characteristics of the PSMC3 variants identified in the subjects included in the study.

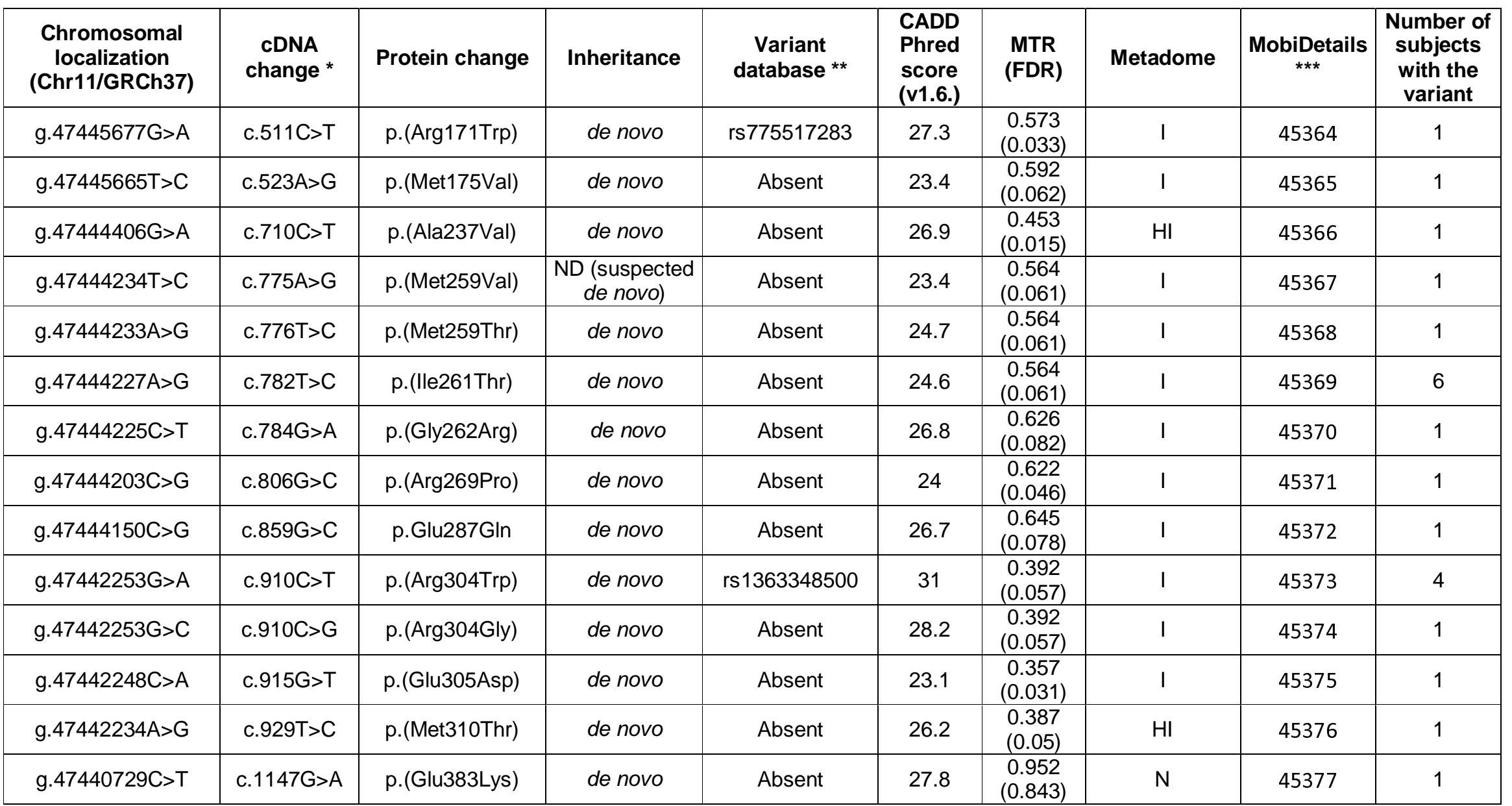


Table 2. Phenotype of subjects with de novo PSMC3 variants (1/3)

\begin{tabular}{|c|c|c|c|c|c|c|c|}
\hline Subject & $\# 1^{a}$ & \#2 & $\# 3^{b}$ & \#4 & \#5 & \#6 & \#7 \\
\hline \multirow[t]{2}{*}{ Variant in $P S M C 3$} & c. $511 \mathrm{C}>\mathrm{T}$ & c. $523 A>G$ & c. $710 \mathrm{C}>\mathrm{T}$ & c. $775 A>G$ & c. $776 \mathrm{~T}>\mathrm{C}$ & c. $782 \mathrm{~T}>\mathrm{C}$ & c. $782 \mathrm{~T}>\mathrm{C}$ \\
\hline & p.(Arg171Trp) & p.(Met175Val) & p.Ala237Val & p.(Met259Val) & p.(Met259Thr) & p.(Ile261Thr) & p.(Ile261Thr) \\
\hline Gender & Male & Female & Male & Female & Male & Female & Female \\
\hline Developmental delay & + & $\mathrm{N} / \mathrm{A}$ & + & + & + & + & + \\
\hline Speech delay & + & $\mathrm{N} / \mathrm{A}$ & $\mathrm{N} / \mathrm{A}$ & + & + & + & $\mathrm{N} / \mathrm{A}$ \\
\hline Facial dysmorphism & $\mathrm{N} / \mathrm{A}$ & $\mathrm{N} / \mathrm{A}$ & + & + & + & + & + \\
\hline Intellectual disability & $\mathrm{N} / \mathrm{A}$ & $\mathrm{N} / \mathrm{A}$ & + & + & + & + & $\mathrm{N} / \mathrm{A}$ \\
\hline Brain MRI anomalies & $\mathrm{N} / \mathrm{A}$ & + & $\mathrm{N} / \mathrm{A}$ & $\mathrm{N} / \mathrm{A}$ & - & + & + \\
\hline Motor delay & $\mathrm{N} / \mathrm{A}$ & $\mathrm{N} / \mathrm{A}$ & $\mathrm{N} / \mathrm{A}$ & - & + & + & + \\
\hline Skeletal malformations & $\mathrm{N} / \mathrm{A}$ & $\mathrm{N} / \mathrm{A}$ & $\mathrm{N} / \mathrm{A}$ & - & + & - & + \\
\hline Gastrointestinal problems & $\mathrm{N} / \mathrm{A}$ & + & $\mathrm{N} / \mathrm{A}$ & - & + & - & - \\
\hline Cardiac malformations & $\mathrm{N} / \mathrm{A}$ & + & + & - & + & - & $\mathrm{N} / \mathrm{A}$ \\
\hline Hypotonia/abnormal tone & $\mathrm{N} / \mathrm{A}$ & $\mathrm{N} / \mathrm{A}$ & $\mathrm{N} / \mathrm{A}$ & + & + & - & - \\
\hline Abnormal behavior & + & $\mathrm{N} / \mathrm{A}$ & $\mathrm{N} / \mathrm{A}$ & - & + & + & - \\
\hline Growth failure & $\mathrm{N} / \mathrm{A}$ & + & $\mathrm{N} / \mathrm{A}$ & - & - & - & - \\
\hline Feeding difficulties & $\mathrm{N} / \mathrm{A}$ & + & $\mathrm{N} / \mathrm{A}$ & - & + & - & - \\
\hline Hearing loss & $\mathrm{N} / \mathrm{A}$ & $\mathrm{N} / \mathrm{A}$ & $\mathrm{N} / \mathrm{A}$ & + & + & - & - \\
\hline Microcephaly & $\mathrm{N} / \mathrm{A}$ & - & $\mathrm{N} / \mathrm{A}$ & - & - & - & $\mathrm{N} / \mathrm{A}$ \\
\hline Other malformations & $\mathrm{N} / \mathrm{A}$ & $\mathrm{N} / \mathrm{A}$ & $\mathrm{N} / \mathrm{A}$ & - & + & $\mathrm{N} / \mathrm{A}$ & - \\
\hline Genital abnormalities & $\mathrm{N} / \mathrm{A}$ & $\mathrm{N} / \mathrm{A}$ & $\mathrm{N} / \mathrm{A}$ & - & + & - & - \\
\hline Renal malformations & $\mathrm{N} / \mathrm{A}$ & $\mathrm{N} / \mathrm{A}$ & - & - & + & - & - \\
\hline Seizures & $\mathrm{N} / \mathrm{A}$ & - & + & - & + & - & - \\
\hline Underweight & $\mathrm{N} / \mathrm{A}$ & + & $\mathrm{N} / \mathrm{A}$ & - & - & - & - \\
\hline Short stature & $\mathrm{N} / \mathrm{A}$ & - & $\mathrm{N} / \mathrm{A}$ & - & $\mathrm{N} / \mathrm{A}$ & - & - \\
\hline
\end{tabular}

* Nomenclature HGVS V2.0 according to mRNA reference sequence NM_002804.4. Nucleotide numbering uses +1 as the A of the ATG translation initiation codon in the reference sequence, with the initiation codon as codon 1.

N/A: parameter not analyzed; 'information retrieved from 'Simons Foundation Powering Autism Research' (SPARK) cohort; ${ }^{\text {binformation }}$ retrieved from 'Deciphering Developmental Disorders' (DDD) cohort. 


\begin{tabular}{|c|c|c|c|c|c|c|c|c|}
\hline Subject & \#8 & $\# 9$ & $\# 10^{b}$ & $\# 11$ & $\# 12$ & $\# 13$ & $\# 14^{\mathrm{b}}$ & \#15 \\
\hline \multirow[t]{2}{*}{ Variant in $P S M C 3$} & c. $782 \mathrm{~T}>\mathrm{C}$ & c. $782 \mathrm{~T}>\mathrm{C}$ & c. $782 \mathrm{~T}>\mathrm{C}$ & c. $782 \mathrm{~T}>\mathrm{C}$ & c. $784 \mathrm{G}>\mathrm{A}$ & c. $806 \mathrm{G}>\mathrm{C}$ & c. $859 \mathrm{G}>\mathrm{C}$ & c. $910 \mathrm{C}>\mathrm{T}$ \\
\hline & p.(Ile261Thr) & p.(Ile261Thr) & p.(Ile261Thr) & p.(Ile261Thr) & p.(Gly262Arg) & p.(Arg269Pro) & p.Glu287Gln & p.(Arg304Trp) \\
\hline
\end{tabular}

Gender

Developmental delay

Speech delay

Facial dysmorphism

Intellectual disability

Brain MRI anomalies

Motor delay

Skeletal

malformations

Gastrointestinal

problems

Cardiac malformations

Hypotonia/abnormal

tone

Abnormal behavior

Growth failure

Feeding difficulties

Hearing loss

Microcephaly

Other malformations

Genital abnormalities

Renal malformations

Seizures

Underweight

Short stature

\begin{tabular}{|c|c|c|c|c|c|c|c|}
\hline Male & Male & Male & Male & Male & Female & Male & Male \\
\hline+ & + & + & + & + & + & + & + \\
\hline+ & + & + & + & + & + & $\mathrm{N} / \mathrm{A}$ & + \\
\hline+ & + & + & + & - & $\mathrm{N} / \mathrm{A}$ & + & + \\
\hline+ & + & + & + & - & + & $\mathrm{N} / \mathrm{A}$ & + \\
\hline- & $\mathrm{N} / \mathrm{A}$ & + & $\mathrm{N} / \mathrm{A}$ & - & + & + & + \\
\hline+ & - & + & - & - & + & $\mathrm{N} / \mathrm{A}$ & + \\
\hline+ & $\mathrm{N} / \mathrm{A}$ & + & - & $\mathrm{N} / \mathrm{A}$ & $\mathrm{N} / \mathrm{A}$ & $\mathrm{N} / \mathrm{A}$ & + \\
\hline+ & + & + & + & - & - & $\mathrm{N} / \mathrm{A}$ & + \\
\hline- & $\mathrm{N} / \mathrm{A}$ & - & - & + & $\mathrm{N} / \mathrm{A}$ & + & + \\
\hline+ & + & + & - & - & + & $\mathrm{N} / \mathrm{A}$ & + \\
\hline+ & - & - & + & - & $\mathrm{N} / \mathrm{A}$ & $\mathrm{N} / \mathrm{A}$ & - \\
\hline- & - & - & - & + & $\mathrm{N} / \mathrm{A}$ & $\mathrm{N} / \mathrm{A}$ & + \\
\hline- & - & - & + & - & $\mathrm{N} / \mathrm{A}$ & $\mathrm{N} / \mathrm{A}$ & + \\
\hline- & - & - & + & + & + & - & + \\
\hline- & - & $\mathrm{N} / \mathrm{A}$ & - & - & $\mathrm{N} / \mathrm{A}$ & $\mathrm{N} / \mathrm{A}$ & + \\
\hline- & - & + & - & $\mathrm{N} / \mathrm{A}$ & $\mathrm{N} / \mathrm{A}$ & + & - \\
\hline- & + & + & - & $\mathrm{N} / \mathrm{A}$ & $\mathrm{N} / \mathrm{A}$ & - & + \\
\hline $\mathrm{N} / \mathrm{A}$ & $\mathrm{N} / \mathrm{A}$ & $\mathrm{N} / \mathrm{A}$ & - & $N / A$ & $\mathrm{~N} / \mathrm{A}$ & - & + \\
\hline- & - & + & + & - & - & - & + \\
\hline- & - & - & - & + & $\mathrm{N} / \mathrm{A}$ & $\mathrm{N} / \mathrm{A}$ & - \\
\hline- & - & - & - & - & - & $\mathrm{N} / \mathrm{A}$ & + \\
\hline
\end{tabular}


902

\begin{tabular}{|c|c|c|c|c|c|c|c|}
\hline Subject & \#16 & \#17 & $\# 18^{b}$ & $\# 19^{b}$ & \#20 & \#21 & \#22 \\
\hline \multirow[t]{2}{*}{ Variant in $P S M C 3$} & c. $910 \mathrm{C}>\mathrm{T}$ & c. $910 \mathrm{C}>\mathrm{T}$ & c. $910 \mathrm{C}>\mathrm{T}$ & c. $910 \mathrm{C}>\mathrm{G}$ & c.915G $>\mathrm{T}$ & c. $929 \mathrm{~T}>\mathrm{C}$ & c. $1147 \mathrm{G}>\mathrm{A}$ \\
\hline & p.(Arg304Trp) & p.(Arg304Trp) & p.(Arg304Trp) & p.(Arg304Gly) & p.(Glu305Asp) & p.(Met310Thr) & p.(Glu383Lys) \\
\hline
\end{tabular}

Gender

Developmental delay

Speech delay

Facial dysmorphism

Intellectual disability

Brain MRI anomalies

Motor delay

Skeletal malformations

Gastrointestinal problems

Cardiac malformations

Hypotonia/abnormal tone

Abnormal behavior

Growth failure

Feeding difficulties

Hearing loss

Microcephaly

Other malformations

Genital abnormalities

Renal malformations

Seizures

Underweight

Short stature

\begin{tabular}{|c|c|c|c|c|c|c|c|}
\hline g304Trp) & p.(Arg304Trp) & p. (Arg304Trp) & p.(Arg304Gly) & p.(Glu305Asp) & p.(Met310Thr) & p.(Glu383Lys) & (22 patients) \\
\hline Male & Female & Female & Female & Female & Male & Male & $13 \mathrm{M} / 9 \mathrm{~F}$ \\
\hline+ & + & + & + & + & + & + & $21 / 21(100 \%)$ \\
\hline+ & + & + & + & + & + & + & $18 / 18(100 \%)$ \\
\hline+ & + & + & + & + & - & + & $17 / 19(89 \% \unrhd$ \\
\hline+ & + & + & + & $\mathrm{N} / \mathrm{A}$ & + & - & $15 / 17$ (88\%) \\
\hline+ & + & $\mathrm{N} / \mathrm{A}$ & + & $\mathrm{N} / \mathrm{A}$ & $\mathrm{N} / \mathrm{A}$ & + & $11 / 14(79 \%)$ \\
\hline+ & + & + & + & + & + & + & $14 / 18(78 \%)$ \\
\hline+ & + & $\mathrm{N} / \mathrm{A}$ & + & + & - & + & $10 / 14(71 \%)^{p}$ \\
\hline+ & $\mathrm{N} / \mathrm{A}$ & $\mathrm{N} / \mathrm{A}$ & - & - & + & + & 10/17 (59\%) z \\
\hline+ & + & + & + & $\mathrm{N} / \mathrm{A}$ & - & - & $10 / 17(59 \%)$ \\
\hline+ & + & $\mathrm{N} / \mathrm{A}$ & + & - & - & - & $10 / 17(59 \%)^{\infty}$ \\
\hline+ & - & $\mathrm{N} / \mathrm{A}$ & + & + & + & - & 9/17 (53\%) \\
\hline+ & + & + & - & + & + & + & $9 / 18(50 \%) \stackrel{\Phi}{\complement}$ \\
\hline+ & + & $\mathrm{N} / \mathrm{A}$ & + & - & - & + & $8 / 17(47 \%) \stackrel{\sum}{=}$ \\
\hline+ & + & $\mathrm{N} / \mathrm{A}$ & - & - & - & - & $8 / 18(44 \%) \stackrel{\circ}{=}$ \\
\hline+ & + & + & - & + & + & - & $6 / 16(38 \%) \stackrel{\Phi}{=}$ \\
\hline+ & $\mathrm{N} / \mathrm{A}$ & $\mathrm{N} / \mathrm{A}$ & - & - & - & + & $5 / 14(36 \%)$ ) \\
\hline- & + & $\mathrm{N} / \mathrm{A}$ & - & - & - & - & $5 / 16(31 \%)$ ㅎํำ \\
\hline+ & + & $\mathrm{N} / \mathrm{A}$ & - & - & - & - & $4 / 14(29 \%)$ \\
\hline- & - & $\mathrm{N} / \mathrm{A}$ & - & - & - & - & $5 / 20(25 \%)$ \\
\hline- & - & $\mathrm{N} / \mathrm{A}$ & - & + & - & + & $4 / 17$ (24\%) \\
\hline- & - & $\mathrm{N} / \mathrm{A}$ & - & + & - & + & $3 / 17(18 \%)$ \\
\hline
\end{tabular}


Table 3. List of proteins enriched in PSMC3 Subjects 16 and 20 versus their controls (mother and father/mother, respectively)

905

\begin{tabular}{|l|l|l|l|l|l|}
\hline $\begin{array}{l}\text { PG.Protein } \\
\text { Groups }\end{array}$ & Protein name & $\begin{array}{l}\text { Gene } \\
\text { name }\end{array}$ & $\begin{array}{l}\text { Mut/Co|signal } \\
\text { log2_ratio }\end{array}$ & Mut/Co|raw_p_value & Mut/Co|adjusted_p_value \\
\hline P02749 & Beta-2-glycoprotein 1 & APOH & 3,90875773 & $3,9233 \mathrm{E}-05$ & 0,01752392 \\
\hline P01861 & $\begin{array}{l}\text { Immunoglobulin heavy constant gamma } \\
4\end{array}$ & IGHG4 & 3,41081457 & $3,9313 \mathrm{E}-07$ & 0,0003951 \\
\hline Q02878 & 60S ribosomal protein L6 & RPL6 & 3,09519982 & $8,1085 \mathrm{E}-05$ & 0,02173071 \\
\hline P62424 & 60S ribosomal protein L7a & RPL7A & 2,97520531 & $2,4946 \mathrm{E}-06$ & 0,00143263 \\
\hline P18124 & 60S ribosomal protein L7 & RPL7 & 2,90834996 & $5,5264 \mathrm{E}-05$ & 0,01815176 \\
\hline P83731 & 60S ribosomal protein L24 & RPL24 & 2,78639617 & $5,8732 \mathrm{E}-05$ & 0,01815176 \\
\hline P16403 & Histone H1.2 & H1-2 & 2,72232694 & $4,4042 E-05$ & 0,0177049 \\
\hline P02768 & Serum albumin & ALB & 2,64236248 & $3,3722 \mathrm{E}-18$ & $1,3556 \mathrm{E}-14$ \\
\hline P36578 & 60S ribosomal protein L4 & RPL4 & 2,50022766 & $3,276 \mathrm{E}-07$ & 0,0003951 \\
\hline P01876 & Immunoglobulin heavy constant alpha 1 & IGHA1 & 2,32067402 & $3,007 \mathrm{E}-05$ & 0,01511011 \\
\hline P20591 & $\begin{array}{l}\text { Interferon-induced GTP-binding protein } \\
\text { Mx1 }\end{array}$ & MX1 & 2,20162951 & $6,3215 \mathrm{E}-05$ & 0,01815176 \\
\hline Q6P2Q9 & Pre-mRNA-processing-splicing factor 8 & $\begin{array}{l}\text { PRPF } \\
8\end{array}$ & 1,33941179 & $1,5549 \mathrm{E}-06$ & 0,00125012 \\
\hline Q01469 & Fatty acid-binding protein 5 & FABP5 & $-2,29088412$ & $5,7962 \mathrm{E}-05$ & 0,01815176 \\
\hline
\end{tabular}


medRxiv preprint doi: https://doi.org/10.1101/2021.12.07.21266342; this version posted December 7, 2021. The copyright holder for this preprint (which was not certified by peer review) is the author/funder, who has granted medRxiv a license to display the preprint in perpetuity.

All rights reserved. No reuse allowed without permission.

Figure Legends

909 Figure 1: Distribution of the de novo heterozygous PSMC3/Rpt5 variants and morphological abnormalities in subjects affected with NDD/ID. $A$. The localization of the

91113 NDD-causing missense variants in the PSMC3/Rpt5 proteins are indicated in red. The

912 AAA-ATPase domain of the PSMC3/Rpt5 proteasome subunit of the 19S regulatory particle 913 is depicted in blue in the schematic representation. Pink circles indicate the presence of 914 variants hotspots. Shown is also a sequence alignment of regions immediately adjacent to 915 the amino acids subjected to missense substitutions. Comparison of the PSMC3 primary 916 structure across six eukaryotic organisms indicates the high conservation of the missense 917 variant residues identified in NDD patients which are highlighted by red boxes. $\boldsymbol{B}$. Facial 918 photos of affected subjects were withdrawn from the present version of the manuscript but 919 can be accessed by querying GestaltMatcher database (https://db.gestaltmatcher.org/) using 920 the term "PSMC3" in the gallery section.

921

Figure 2: Pan-neuronal disruption of PSMC3/Rpt5 results in normal learning performance but defective reversal performance. A. A T-maze, depicting standard conditioning of odour-avoidance response in which Drosophila flies are trained to avoid one particular odour chamber which is associated with a foot-shock (in this example, odour chamber 1). B. Schematic illustration of the experimental timelines of the learning and reversal learning protocols used in these experiments. Reversal learning is assessed by reversing odour shock pairing $(\mathrm{MCH}-, \mathrm{OCT}+)$, as indicated. $\boldsymbol{C}$. Upper left: no significant difference was detected in learning with pan-neuronal expression of Rpt5 RNAi for Rpt5 $5^{32422}$ $(P=0.6435, N=4)$. Upper right: similarly, pan-neuronal expression of Rpt5 RNAi for Rpt5 ${ }^{53886}$ resulted in no significant difference in learning $(P=0.5282, N=6)$. Lower left: reversal learning was significantly defective with pan-neuronal Rpt5 RNAi expression for $R p t 5^{32422}(P<0.0001$,

$933 \mathrm{~N}=4)$. Lower right: pan-neuronal Rpt5 RNAi expression for $R p t 5^{53886}$ also resulted in 934 significant learning defects $(P=0.0022, N=6)$. 
medRxiv preprint doi: https://doi.org/10.1101/2021.12.07.21266342; this version posted December 7, 2021. The copyright holder for this preprint (which was not certified by peer review) is the author/funder, who has granted medRxiv a license to display the preprint in perpetuity.

All rights reserved. No reuse allowed without permission.

936 Figure 3: PSMC3/Rpt5 variants do not behave similarly at the molecular level. $A$.

937 SHSY5Y cells were transfected with HA-tagged PSMC3 mutants for $24 \mathrm{~h}$ prior to protein

938 extraction and western-blotting using antibodies specific for PSMC3 and HA, as indicated.

939 Both non-transfected and mock-transfected cells served as negative controls. Equal protein

940 loading was ensured by probing the membranes with an anti-a-tubulin monoclonal antibody.

941 Shown is one representative experiment out of two. B. SHSY5Y cells transfected with the

942 various HA-PSMC3 variants were subjected to total RNA extraction followed by semi-

943 quantitative RT-PCR using primer located in PSMC3 and the polyadenylation signal of the

944 pcDNA3.1/myc-HIS expression vector $(\mathrm{BGH})$. Equal loading between the samples was

945 ensured by amplifying the RPL0 gene, as indicated. C. A sliced surface view of the $26 \mathrm{~S}$

946 proteasome (grey) was superimposed with a cartoon representation of the subunits

947 PSMC3/RPT5 (blue) and PSMB1/a6 (purple) as well as the substrate (orange). The

948 ATP/ADP molecules of the AAA-ATPase ring are shown as green sticks, while the

949 investigated missense variants as bright yellow spheres. $\boldsymbol{D}$. Detailed representation of the

950 missense variants in the loop region of the $N$-terminal $\alpha / \beta$ domain. Residues affected by

951 variants are involved in a polar interaction network close to the substrate tunnel. $\boldsymbol{E}$. Close up

952 view on the RPT5-a6 interface affected by the p.(Glu383Lys) variant. Residues affected by

953 variants are shown as bright yellow balls and sticks with atoms coloured by polarity (oxygen

954 in red, nitrogen in blue and sulphur in dark yellow). Figures were created with PyMOL v. 2.0

955 (pymol.org) using the human 26S proteasome structure (PDB-entry code: 6MSK [44]).

956

957 Figure 4: PSMC3/Rpt5 variants cause proteasome assembly defects in individuals with

958 NDD/ID. A. Five to twenty micrograms of RIPA lysates from T cells isolated from Subjects

$959 \# 12, \# 17$ and \#20 as well as related controls (index case's father and/or mother) were

960 separated by SDS-PAGE followed by western-blotting using antibodies directed against

961 PSMC3/Rpt5, PSMD12/Rpn5, PA28- $\alpha$ and Alpha7, as indicated. Equal protein loading was

962 ensured by probing the membrane with an anti-a-tubulin antibody. $\boldsymbol{B}$. Twenty micrograms of 
medRxiv preprint doi: https://doi.org/10.1101/2021.12.07.21266342; this version posted December 7, 2021. The copyright holder for this preprint (which was not certified by peer review) is the author/funder, who has granted medRxiv a license to display the preprint in perpetuity.

All rights reserved. No reuse allowed without permission.

963 native whole-cell lysates derived from T cells isolated from NDD Subjects \#12, \#17 and \#20

964 as well as related controls (index case's father and/or mother) were separated by $3-12 \%$

965 native-PAGE prior to suc-LLVY-AMC in-gel activity assay to visualize the positions of the

$96620 S$ and 265 proteasome complexes. Gels were subsequently transferred to blots and

967 probed with antibodies specific for Alpha6, PSMC3/Rpt5, PSMD12/Rpn5 and PA28-a, as

968 indicated.

969

970

Figure 5: Proteomic signatures of NDD/ID subjects carrying PSMC3/Rpt5 variants.

971

Heatmap cluster analysis showing the similarities in the protein expression profiles of the

PSMC3 Subjects \#16 and \#20 (carrying the p.Arg304Trp and Glu305Asp PSMC3 variants, respectively) compared to their related controls (father and/or mother of the proband), as indicated. Only the differentially expressed proteins with an absolute value of log2 foldchange greater than 2 were selected for the clustering analysis.

976

Figure 6: NDD/ID subjects carrying PSMC3/Rpt5 variants exhibit severe signs of protein homeostasis perturbations and alterations of the UPR, ISR and autophagy/mitophagy pathways. A. Five to twenty micrograms of RIPA lysates from T cells isolated from subjects \#12, \#16, \#17 and \#20 as well as related controls (PSMC3 index case's father and/or mother) were separated by SDS-PAGE followed by western-blotting using antibodies directed against K48-linked ubiquitin-modified proteins, GRP94, IRE1, 983 phospho-IRE1, elF2 $\alpha$, phospho-elF2 $\alpha$, GADD34, CReP, PKR, phospho-PKR and GAPDH 984 (loading control), as indicated. B. RIPA-cell lysates from Subjects \#12, \#16, \#17 and \#20 as well as their related controls (PSMC3 index case's father and/or mother) were subjected to SDS-PAGE/western-blotting using antibodies specific for LC3b, PINK1, BNIP3L and atubulin (loading control), as indicated.

Figure 7: NDD/ID subjects with PSMC3/Rpt5 missense variants exhibit a typical type I 
medRxiv preprint doi: https://doi.org/10.1101/2021.12.07.21266342; this version posted December 7, 2021. The copyright holder for this preprint (which was not certified by peer review) is the author/funder, who has granted medRxiv a license to display the preprint in perpetuity.

All rights reserved. No reuse allowed without permission.

991 from PSMC3 subjects and their relative controls (father and/or mother of the proband). Each

992 column represents one individual patient/related control and each row represents one gene.

993 Clustering of genes and samples was carried out by centred Pearson correlation. Colour 994 indicates normalized counts of each gene, with green representing higher expression and 995 red relatively lower expression. B. Gene expression of six typical IFN-stimulated genes 996 (IFIT1, IFI27, IFI44, IFI44L, ISG15 and RSAD2) was assayed by RT-qPCR on T cells derived 997 from the NDD/ID Subjects \#12 (A), \#16 (B), \#17 (C) and \#20 (D) as well as their respective 998 controls (PSMC3 index case's father and/or mother). Expression levels were normalized to 999 GAPDH and relative quantifications (RQ) are presented as fold change over controls. Shown 1000 is also the median fold expression of the six ISG over relative controls. Statistical significance 1001 was assessed by ratio paired $t$ test where *indicates $p<0.05$, ${ }^{* *}$ indicates $p<0.01$ and ${ }^{* * *}$ 1002 indicates $p<0.001$.

1003

1004

Figure 8: Interferon (IFN) score of PSMC3 subjects suffering from NDD/ID. IFN scores

1005 for the NDD/ID families \#12, \#16, \#17 and \#20 (related controls and affected individuals) as 1006 well as for six unrelated controls (1 to 6$)$ were calculated as the median of the $R Q$ of the six 1007 ISG over a single calibrator control. Shown are the IFN scores of each sample (left panel) 1008 and the sample groups i.e. related controls, unrelated controls and PSMC3 subjects, as 1009 indicated (right panel). Statistical significance was assessed by ratio paired t test where *indicates $p<0.1$ and ** indicates $p<0.05$.

1011

1012 


\section{Figure 1}

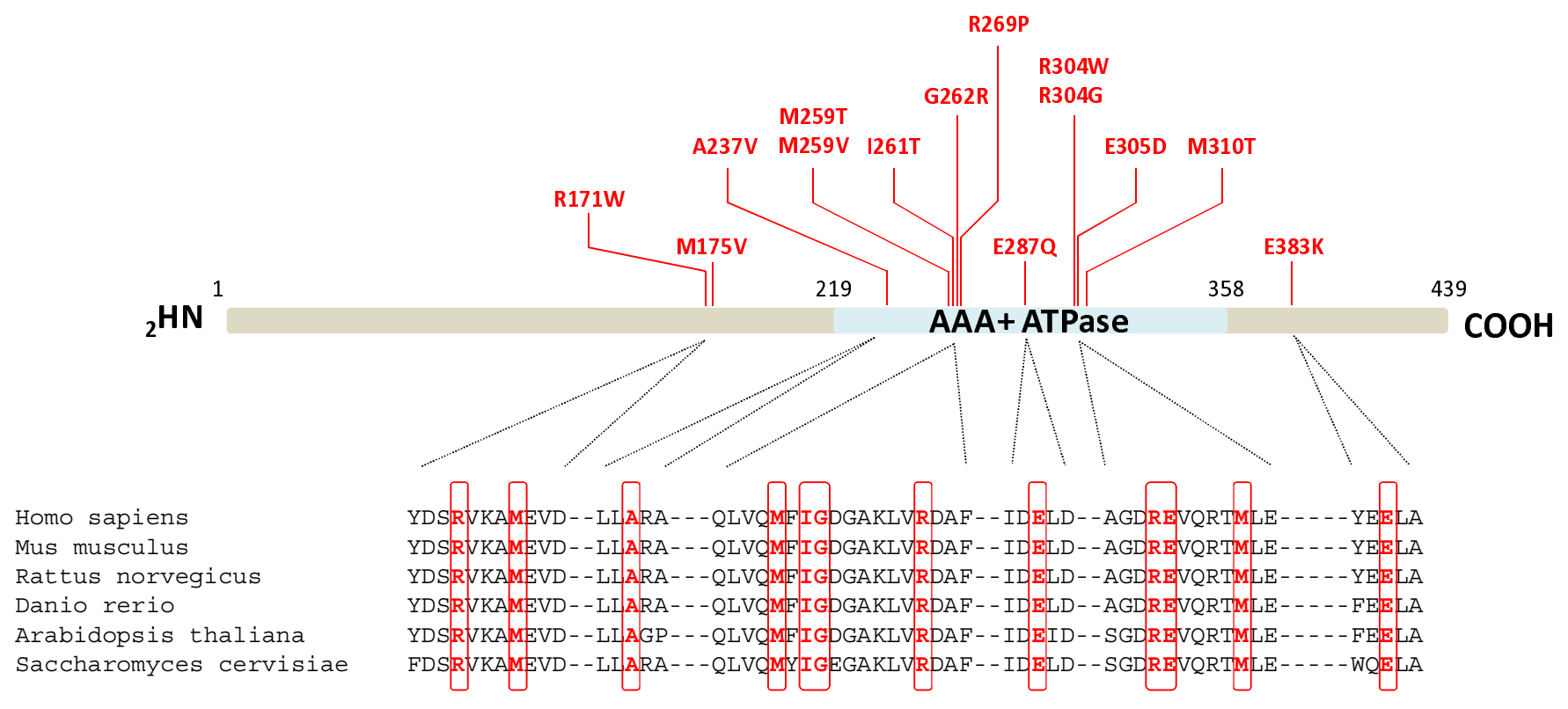


Figure 2

A

B

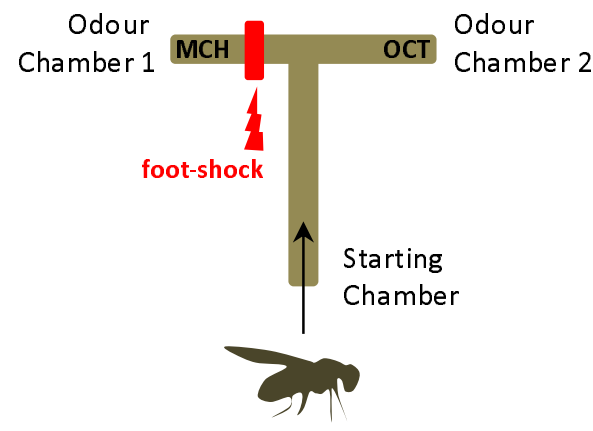

Learning

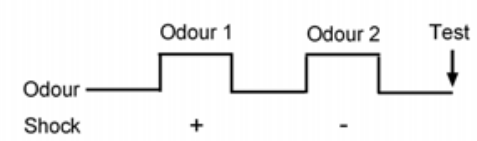

Reversal Learning

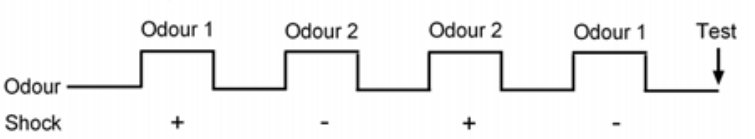

C

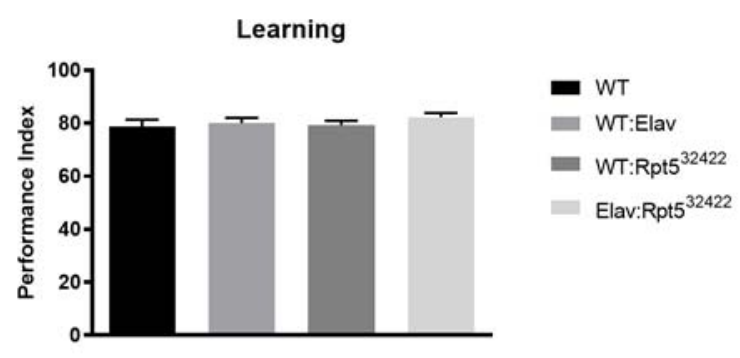

Reversal Learning

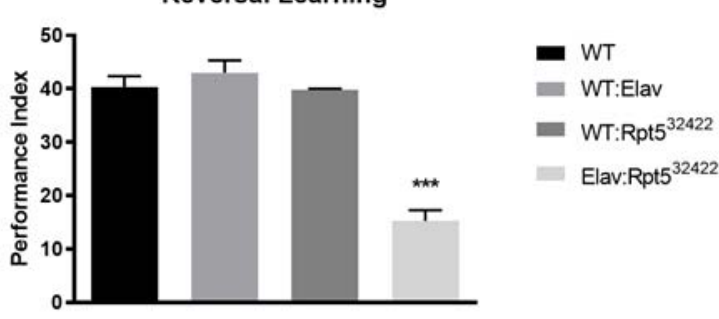

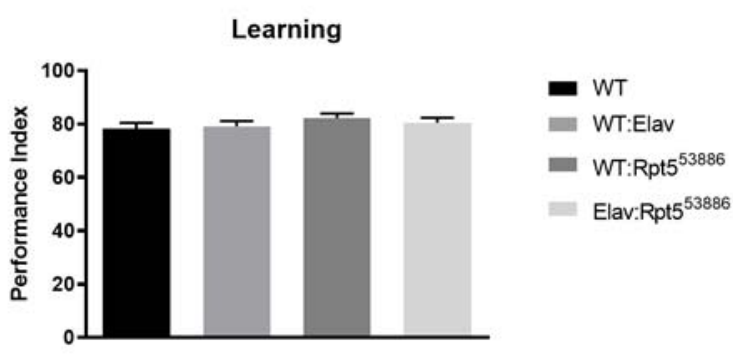

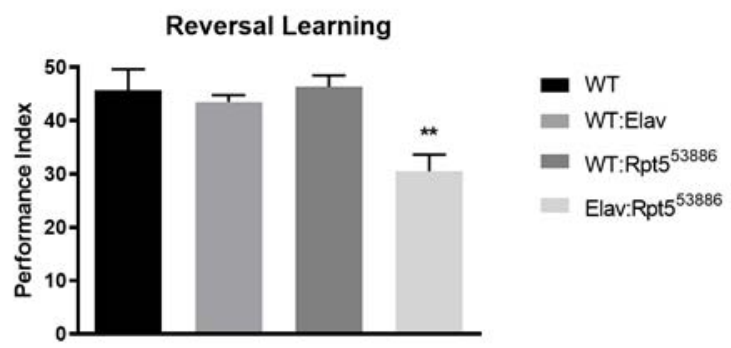




\section{Figure 3}

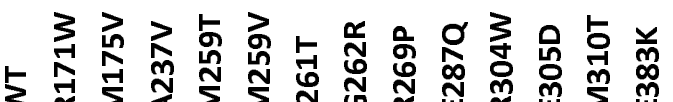
作

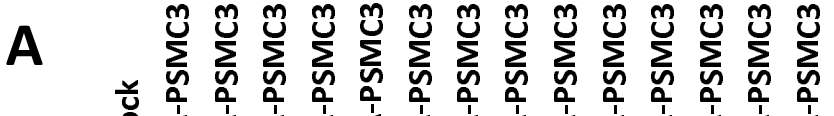

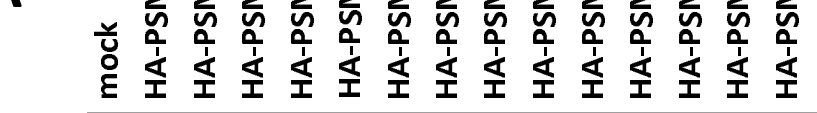

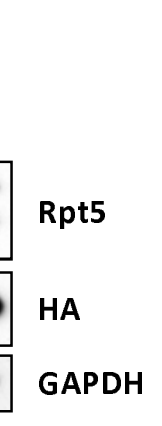

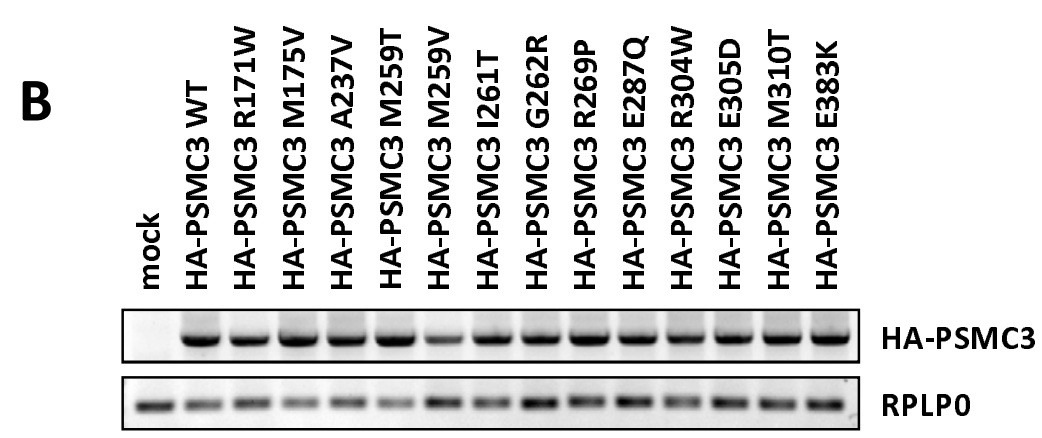
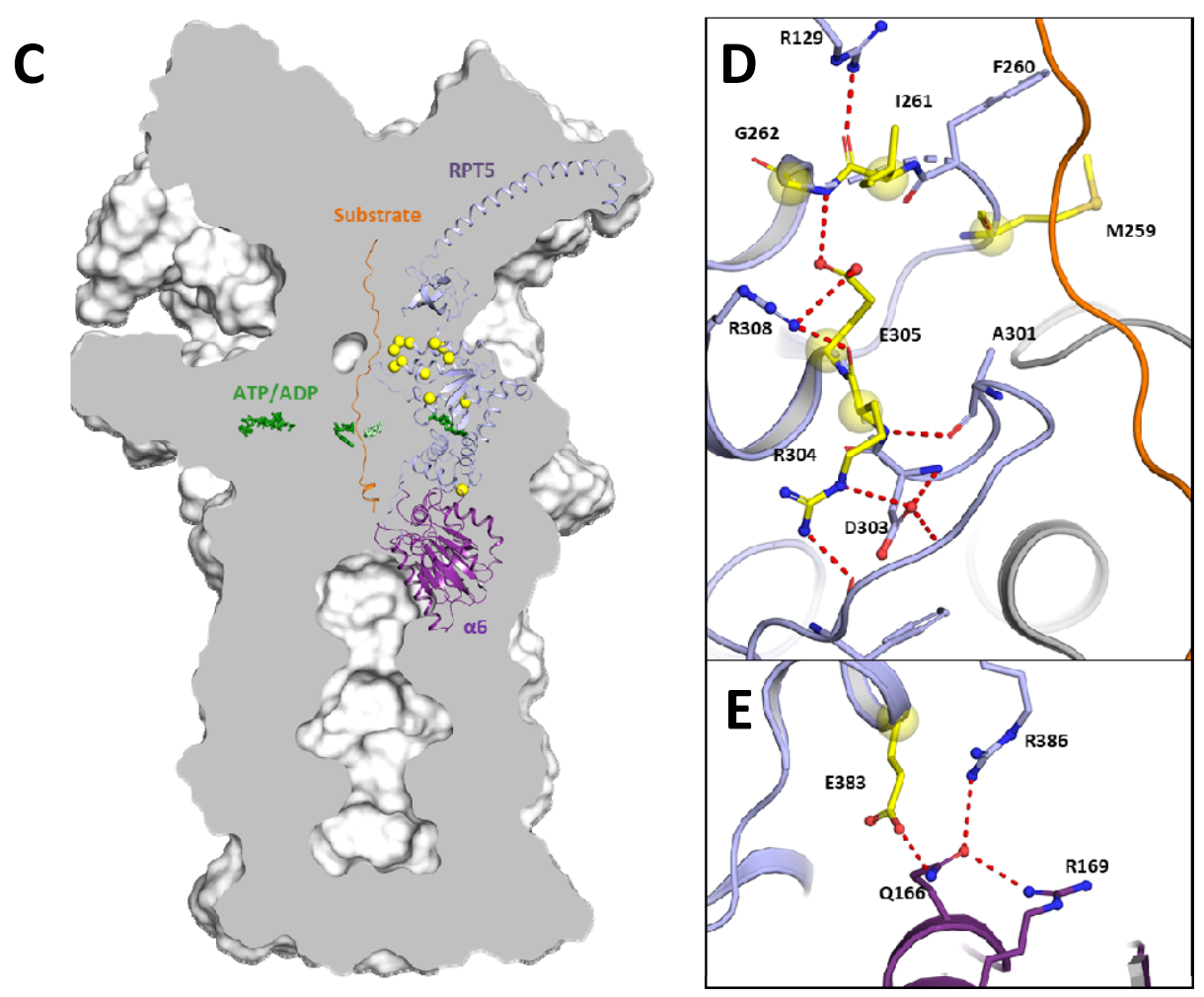


\section{Figure 4}

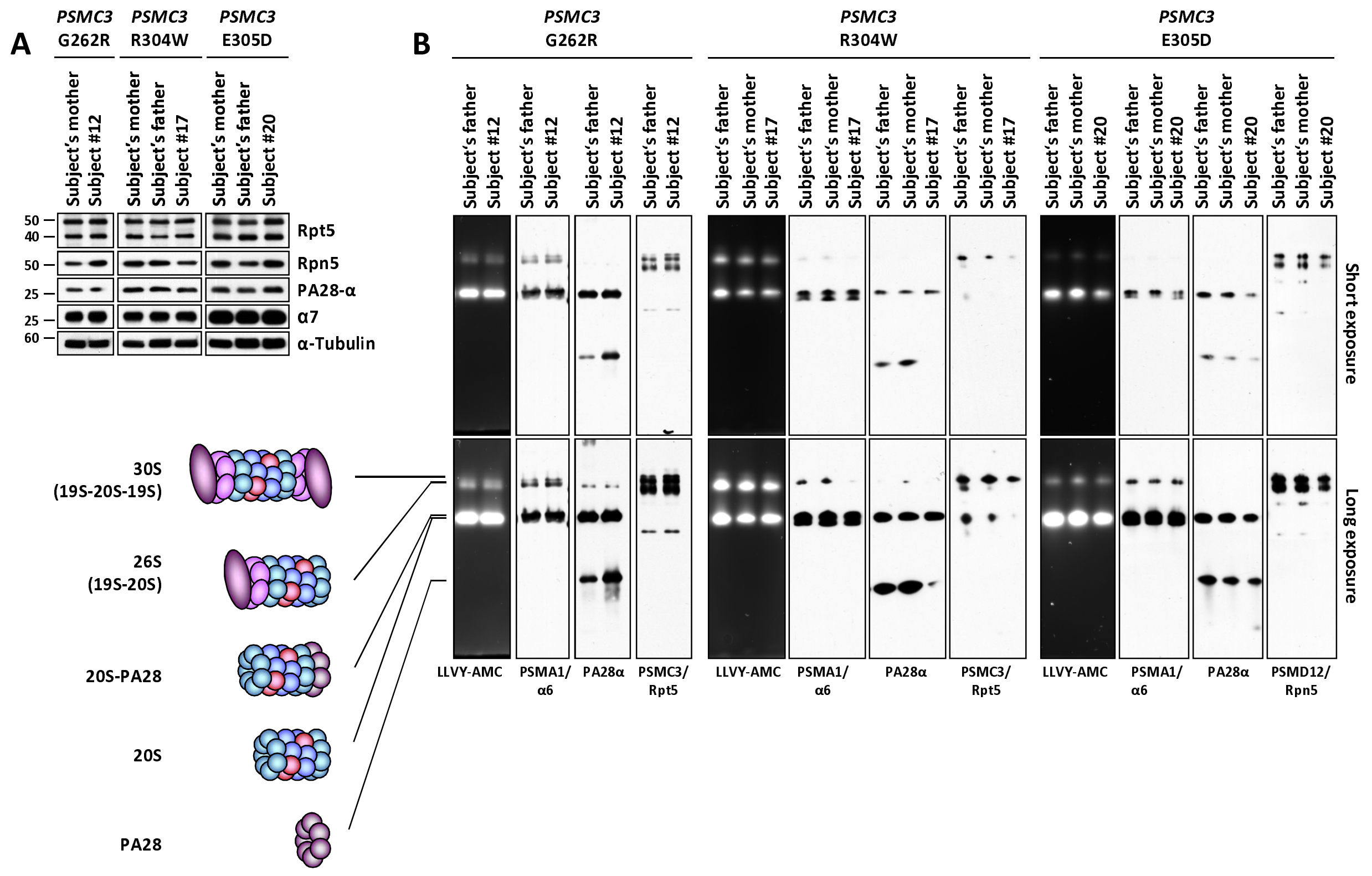




\section{Figure 5}

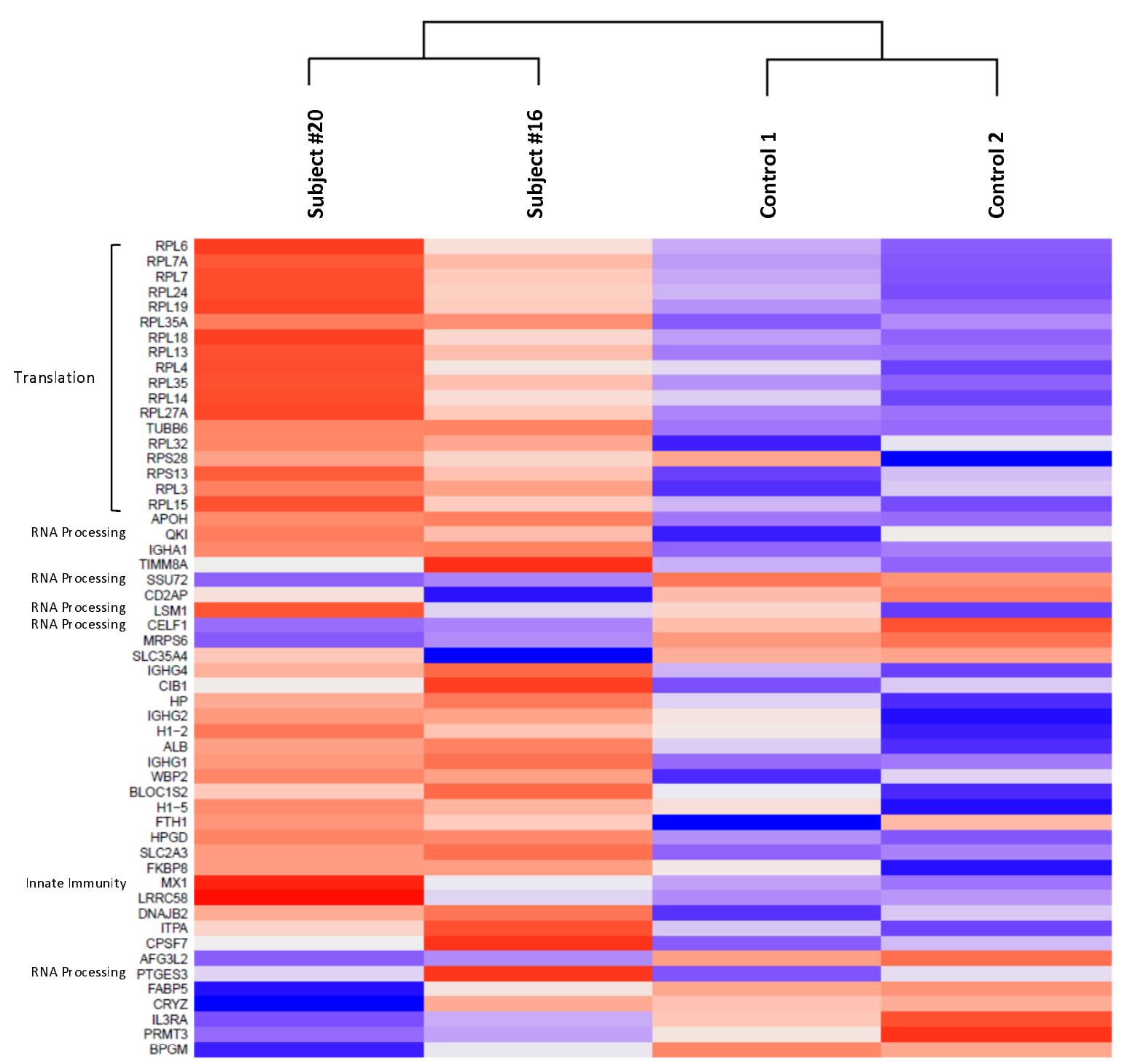




\section{Figure 6}
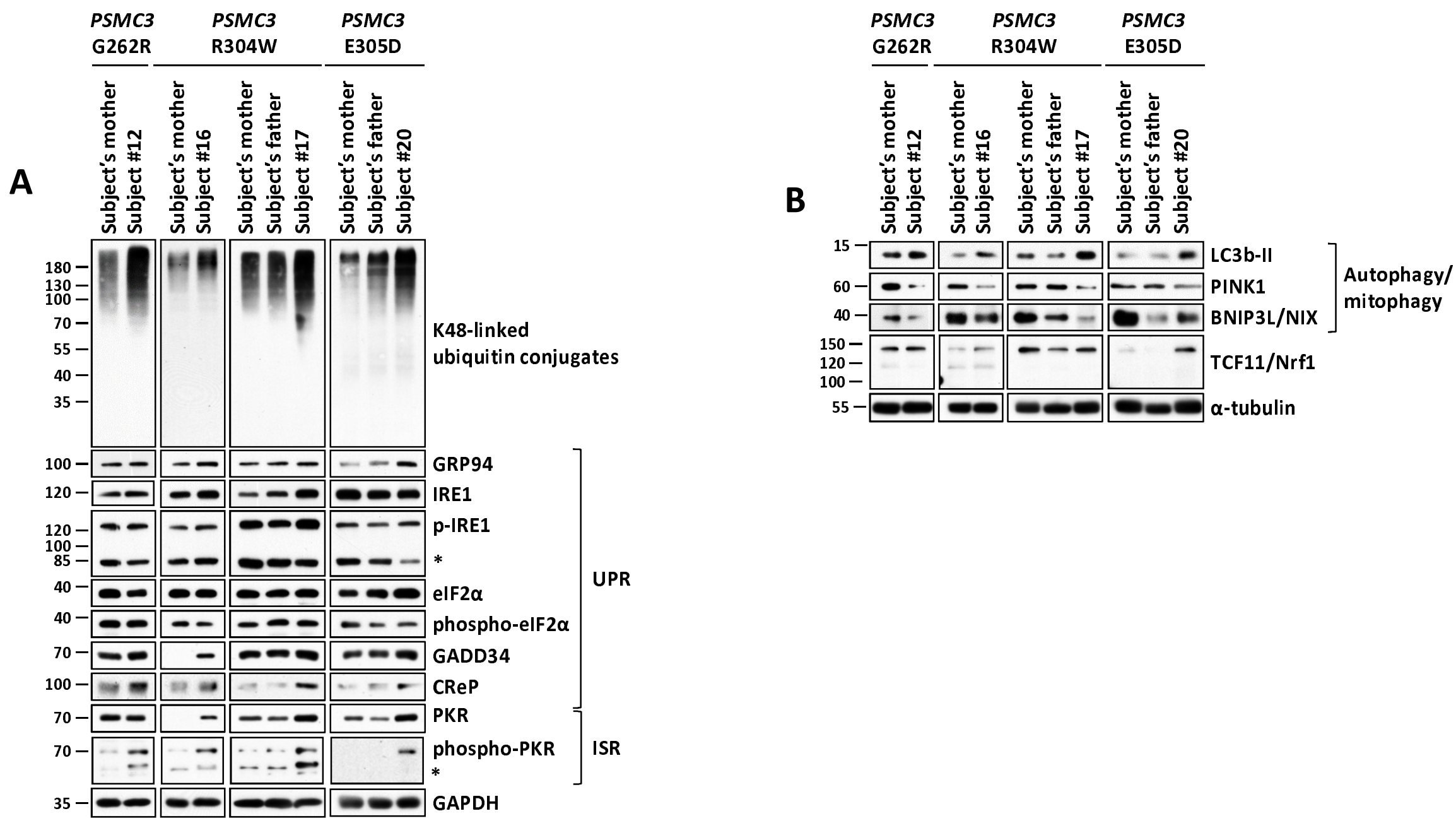

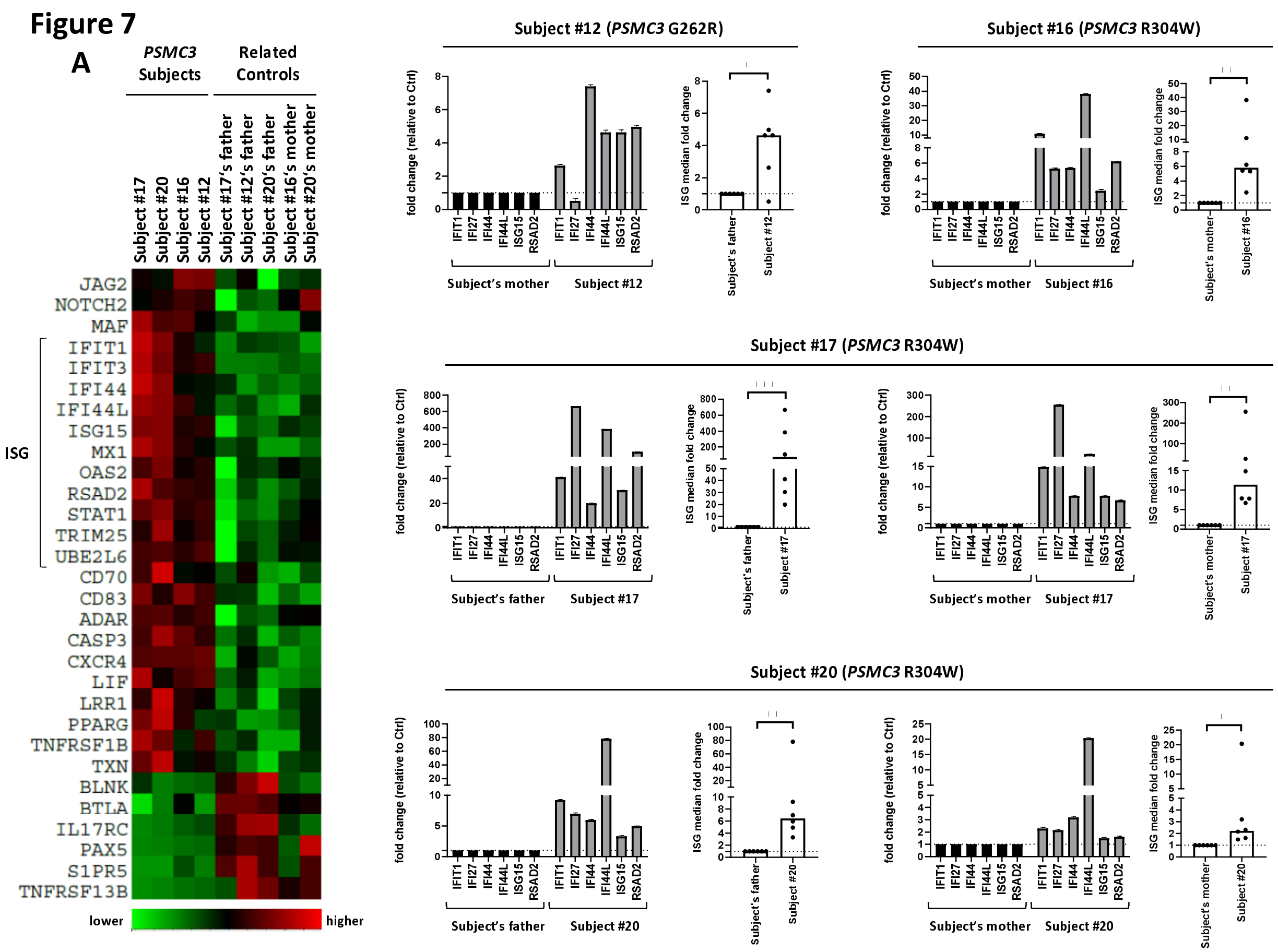


\section{Figure 8}
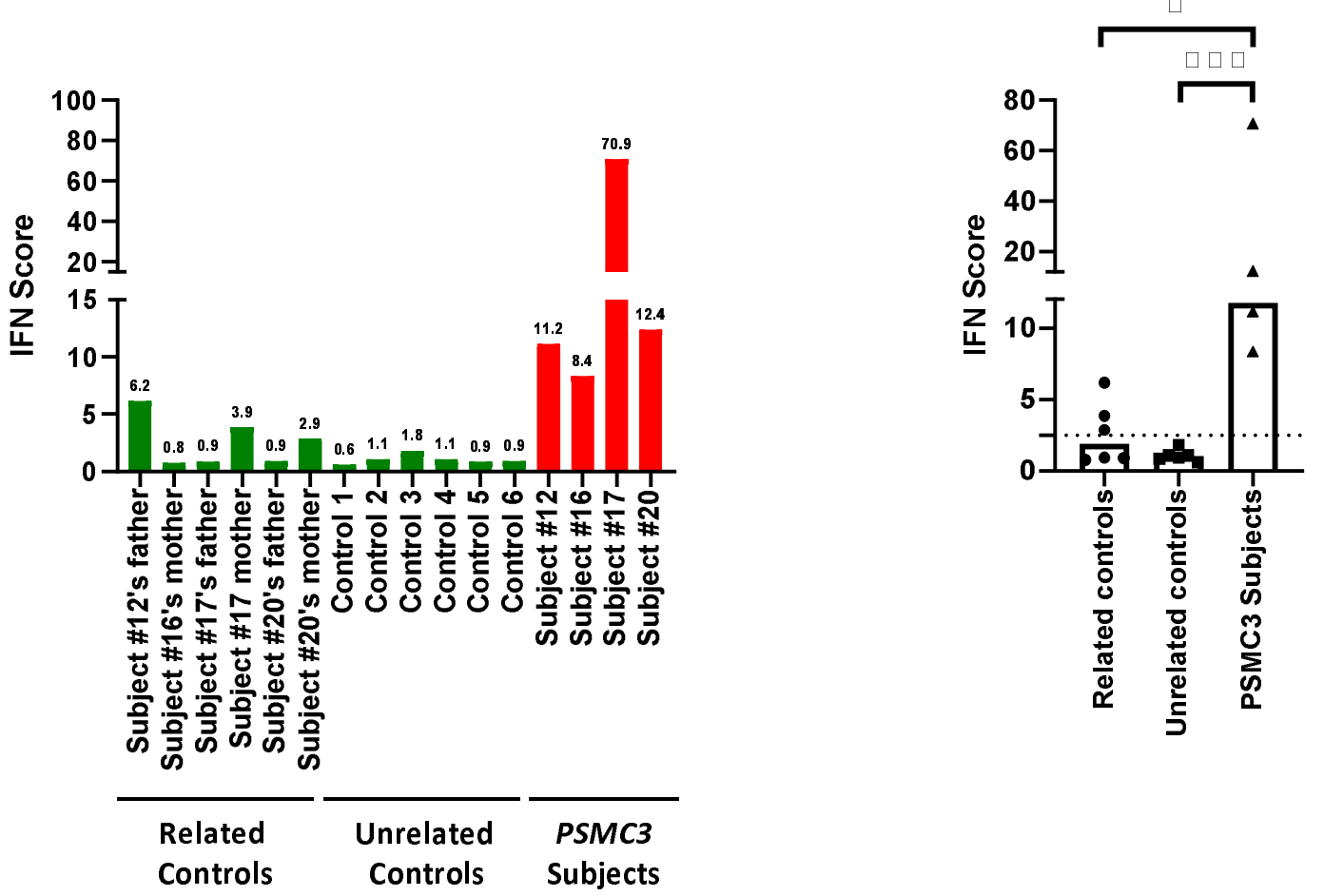